\title{
LOCAL LABOR MARKETS AND \\ WELFARE SPELLS: DO DEMAND CONDITIONS MATTER?
}

Hilary Williamson Hoynes

Working Paper 5643

\section{NATIONAL BUREAU OF ECONOMIC RESEARCH 1050 Massachusetts Avenue \\ Cambridge, MA 02138 \\ June 1996}

I am grateful to Timothy Bartik, Becky Blank, Nada Eissa, Jonathan Gruber, Larry Katz, Jacob Klerman, Jonathan Leonard, Robert Moffitt, Jim Poterba and to seminar participants at Columbia, Dartmouth, Harvard, MIT, Princeton, Yale, and workshops at IRP and the NBER Summer Institute for useful comments. I also would like to thank Lois Van Beers, Susan Ayasse, Henry Brady, and Werner Schink for assistance with the LDB data. Cindy Gustafson has provided excellent research assistance. Financial support was received from the National Institute for Child Health Development and computing support was provided by the Econometrics Laboratory at UC Berkeley. This paper is part of NBER's research programs in Labor Studies and Public Economics. Any opinions expressed are those of the author and not those of the National Bureau of Economic Research.

(C) 1996 by Hilary Williamson Hoynes. All rights reserved. Short sections of text, not to exceed two paragraphs, may be quoted without explicit permission provided that full credit, including (C) notice, is given to the source. 


\title{
LOCAL LABOR MARKETS AND \\ WELFARE SPELLS: DO DEMAND \\ CONDITIONS MATTER?
}

\begin{abstract}
This paper examines the role of local labor markets in determining how long families receive benefits from the Aid to Families with Dependent Children (AFDC) program. Given the current policy emphasis on devolution and reducing the AFDC caseload through employment, understanding the role of local labor demand is important. The study uses a unique data set based on administrative data which has detailed information on welfare spells for over 100,000 AFDC cases. The empirical work is based on estimates of a duration model where the hazard rate is a function of demographic characteristics, local labor market variables, neighborhood characteristics, county fixed effects and time effects. Several alternative measures of local labor market conditions are used and the results show that higher unemployment rates, lower employment growth, lower employment to population ratios, and lower wage growth are associated with longer welfare spells. On average, a typical employment fluctuation over the business cycle, if permanent, would lead to an 8-10 percent reduction in the AFDC caseload. Typical changes in real quarterly eamings generate somewhat smaller effects. The combined effect of these two changes, if permanent, would lead to sizeable reductions in the caseload, on the order of 15 percent. The estimated labor market effects are robust to including county level fixed effects and time effects. AFDC-UP participants, blacks, and residents of urban areas are more sensitive to changes in economic conditions while teen parents and refugee groups are found to be much less sensitive to changes in local labor market conditions.
\end{abstract}

Hilary Williamson Hoynes

Department of Economics

549 Evans Hall

University of California, Berkeley

Berkeley, CA 94707-3880

and NBER 


\section{Introduction}

There is currently a great deal of interest among policy makers and the general public in reforming the welfare system. While there exists very divergent views as to how the programs should be reformed, there seems to be a consensus that employment should play a central role in reducing reliance on public assistance. Most prominent proposals for modifying the Aid to Families with Dependent Children (AFDC) program, for example, involve increasing the work activities of recipients either through mandatory work programs, training programs or time limiting of benefits. However, despite the belief that pursuing employment strategies will reduce welfare dependency, little is known about the factors that contribute to achieving independence.

What we do know is that employment has become a very important factor in facilitating transitions off welfare. Among female headed households, changes in the employment status of the mother is the characteristic most commonly associated with an exit from welfare, accounting for as much as one half of exits among AFDC recipients (Blank 1989, Blank and Ruggles 1996, Fitzgerald 1995, Gritz and MaCurdy 1992, Harris 1993, Pavetti 1993). ${ }^{1}$ However, remarkably little is known about the factors which determine these exits from welfare. The literature has examined the importance of supply side factors such as education, family structure, job training and placement programs and the availability of transitional benefits for child care and medical care as well as examining the role of program incentives such as the benefit level and implicit tax rate on earned income. At the same time, we would also expect that the level of wages and availability of job opportunities would affect the affect the length of time on welfare. These demand side factors have received little attention in the literature.

Understanding the link between macroeconomic conditions and welfare utilization is important for several reasons. First, to what extent can economic growth alone reduce welfare reliance? Can a regime

'Earlier work found that marriage was the most common route off welfare (Bane and Ellwood 1983). Marriage may represent a more permanent route off welfare as those exiting via work are more likely to return to welfare (Pavetti 1993). 
of high employment growth and increasing real earnings significantly reduce the welfare rolls? Second, understanding the role of local labor market conditions may also be of direct importance to the policy debate. Time limiting welfare benefits is an integral part of almost all existing welfare reform proposals and many states are currently experimenting with imposing these limits (Savner and Greenberg 1995). While this represents a significant change for public assistance programs in the U.S., the new program would more closely resemble the Unemployment Insurance (UI) system, where benefits are limited, initially, to a period of 26 weeks. Implementing a time limit, however, raises the issue of equity across areas which have varying labor market conditions. The UI system addresses this by extending benefits for an additional period if the state has relatively high unemployment rates. Linking time limitations in welfare receipt to local unemployment rates has been raised in welfare reform discussions but was abandoned in part because the empirical research provided no evidence supporting a link between local labor markets and welfare dependency. Further, devolution of responsibility to the states would result in less opportunities for risk pooling across areas leaving the state vulnerable to labor market shocks. This is reflected in proposals to set up "rainy day" funds to cover such possibilities (Sawhill 1995).

The available evidence does not make a strong case for a link between length of time on welfare and labor market conditions. This literature, however, suffers from two limitations. First, most studies utilize state level labor market controls which may not accurately measure employment opportunities. This literature consistently finds small and statistically insignificant effects. For example, Hoynes and MaCurdy $(1993,1994)$ find that labor market conditions, measured by state unemployment rates and average wages, play no role in explaining changes over time in the length of welfare spells among female heads of household. Other studies (Fitzgerald 1995, Harris 1993, Sanders 1992) use county or grouped counties to define local labor markets and find mixed evidence on the importance of the labor market. These studies, however, rely primarily on cross-area differences to identify the effect of labor markets. To the extent there may be omitted variables correlated with both labor market conditions and AFDC utilization, these estimates may be biased. For example, welfare recipients with low education levels and little labor 
market experience may be more likely to live in areas with adverse labor markets. In this case, incomplete measures of individual characteristics would lead to an overestimate of the effect of labor markets. The importance of these cross-area differences has not been demonstrated in the literature.

A significant barnier to doing research on the impact of local labor markets is the data requirements. First, one needs longitudinal data in order to track welfare spells. Second, one needs information on geographic location to assign local labor market variables. Lastly, one needs sufficient sample sizes to examine a broad set of covariates for the relevant subsamples of the recipient population. No data set used in the literature satisfies these conditions. Researchers in this area have primarily relied on the Panel Study of Income Dynamics (PSID), but have also used the National Longitudinal Survey of Youth (NLSY) and the Survey of Income and Program Participation (SIPP). The geographic area identified in these data is typically the state (PSID, SIPP), or SMSA, and sometimes county (NLSY). In all of these surveys, the sample sizes for female heads of household receiving welfare are quite small, on the order of 1,000 for the PSID, the SIPP, and the NLSY.

This study uses a unique new data set to comprehensively examine the role of local labor market conditions in determining how long families receive benefits in the AFDC program. The Longitudinal Database (LDB) contains a 10 percent sample of all AFDC cases in California from 1987-1992. The sample is based on administrative data and includes information on monthly utilization of AFDC for about 100,000 cases over this period (UC Data, 1994). The data set identifies the county and zip code of residence which is used to assign labor market variables at the county level while controlling for the characteristics of the neighborhood of residence using summary tabulations from the 1990 Census. Many measures of local labor market conditions are used including unemployment rates, employment growth by sector, employment to population ratios, average earnings by sector, and industrial composition of employment.

The LDB data also contain demographic information which is used to examine how the determinants of welfare experiences differ for families with different characteristics. For example, two 
parent families are eligible to receive benefits as part of the AFDC-Unemployed Parent (AFDC-UP) program and differ from female heads of household in terms of their labor market history, characteristics and behavioral responses to program changes (Hoynes 1996). However, they represent less than ten percent of the total AFDC caseload (U.S. House of Representatives 1994) and, accordingly, have received little attention in the literature. The empirical model allows for differences between female heads of household and intact families; for teen and non-teen parents; for urban and non-urban families; and for various racial and ethnic groups. This is not only important for examining which groups are more likely to benefit from strong economic conditions but may also examine some as yet unexplained higher rates of welfare dependency among various groups such as blacks and urban residents.

The results are estimated using a discrete duration model where the monthly exit probability is a function of demographic characteristics, local labor market variables, neighborhood characteristics, and fixed time and county effects. The results show that higher unemployment rates, lower employment growth, lower employment to population ratios, and lower wage growth are associated with longer welfare spells. The results are consistent across the different specifications for labor market variables and are robust to including fixed county and time effects. Overall, the estimated effects are statistically significant and important. A 10 percent increase in employment or a 5 percent increase in real earnings would lead to a 5-9 percent increase in the likelihood that a spell lasts one year or less. Blacks, residents of urban areas, and AFDC-UP recipients are more sensitive to changes in economic conditions while teen parents and refugee groups are much less sensitive to local labor market conditions.

The broader policy question is to what degree do changes in economic conditions affect the AFDC caseload and program expenditures. The size of the caseload is determined by entry rates and length of spell conditional on entry, both of which may be affected by local economic conditions. I have decided to focus my attention first on the determinants of the length of spell primarily because studies examining the routes of entry into and exit out of welfare suggests that changes in labor market status are more likely to be associated with exits from welfare than with entry into welfare (Bane and Ellwood, 1983; Gritz and 
MaCurdy, 1992). Bane and Ellwood state that "The fact that so few spells of AFDC begin with earnings changes suggests that it is not typically the case that a female household head goes on AFDC because she has lost her job, reduced her hours, or experienced a drop in wages" (p.19). This may or may not be true, however, and future work will examine the effects on entry. ${ }^{2}$

The remainder of the paper proceeds as follows. Section 2 reviews the literature on economic effects of local labor market conditions on welfare and employment. Section 3 describes the data and presents the descriptive statistics. Section 4 describes the empirical model and Section 5 presents descriptive statistics for the estimation data set. The results are presented in Section 6 and Section 7 concludes.

\section{Background}

The majority of the literature examining the determinants of welfare dependency focuses on the supply side as opposed to the demand side. Bane and Ellwood (1983) present the first estimates of spell durations and the determinants of welfare dependency. They estimate the probability of exiting from welfare as a function of individual characteristics, AFDC benefits, and length of spell, based on a sample of female heads of household from the Panel Study of Income Dynamics (PSID). Similar approaches based on a variety of different data sets are found in Blank (1989), Blank and Ruggles (1996), Ellwood (1986), Fitzgerald (1992), Gritz and MaCurdy (1992), Harris (1993), Hoynes and MaCurdy (1993, 1994), and ONeill et. al $(1984,1987){ }^{3}$ These studies estimate that the likelihood of leaving welfare decreases as the spell length increases and that spells are likely to be longer for younger, unmarried, non-white women with larger families and lower education levels living in states with higher benefit levels. Those studies that

\footnotetext{
${ }^{2}$ Sanders (1992), in fact, finds a larger effect of labor markets on entry than on exit for a sample of young women. More generally, the literature examining routes into and out of welfare has focused on the direct effects of labor markets. We might also expect indirect effects of the labor market though its effect on family structure outcomes such as divorce and fertility (Duncan and Hoffman 1990).

${ }^{3}$ For a review of the welfare dynamics literature see Moffitt (1992).
} 
examine the routes off welfare (Blank 1989, Blank and Ruggles 1996, Ellwood 1986, Harris 1993), find that the variables most important for increasing the likelihood of an "earnings related" exit from welfare are education, work experience, marital status (previously married), and number of children (fewer).

While not the focus of these studies, most control for job opportunities in the state by including the state unemployment rate and the coefficient is typically small and statistically insignificant. This may be because the state is too large a jurisdiction for measuring labor market opportunities. A few studies use county or grouped county level labor market controls and find some evidence that local labor market conditions matter. Harris (1993) uses the PSID and finds that women living in counties with lower unemployment rates are more likely to have shorter spells and are more likely to leave via work. Sanders (1992) uses a sample of young women from the NLSY and finds that lower county unemployment rates lead to higher rates of entry into AFDC and lower rates of exit. Fitzgerald (1995) uses a sample of female heads of household from the SIPP appended with "labor market area" employment and unemployment data. These labor market areas are groups of counties and resemble SMSAs in urban areas, but also group together rural counties. ${ }^{4} \mathrm{He}$ finds that strong labor market conditions are associated with shorter spells for blacks, but do not significantly affect whites.$^{5}$ In each of these studies, however, the effect of the labor market variable is identified primarily off of cross-area differences in labor market conditions. If there are any omitted area characteristics which are correlated with the labor market variables then the results will be biased. For example, areas with high unemployment rates may partially be reflecting the weaker job skills of its residents. Other omitted variables such as differences in the cost of living and county services for job placement and job search may also be important.

The importance of omitted area variables is addressed by Fitzgerald (1994). When he introduces labor market area fixed effects, the labor market variables become small and statistically insignificant for

\footnotetext{
${ }^{4}$ The public release version of each of the SIPP data sets identifies only the state of residence. Fitzgerald received access to this confidential data on county of residence while working as a Census Department Fellow.

'In addition, Blank (1989) uses SMSA level unemployment rates and finds that no significant relationship. Her sample, however, consists of data from only two cities, Seattle and Denver.
} 
both whites and blacks. He suggests that this may be due to insufficient variation in the labor market conditions over time (p.12), but may also be due to relatively small sample sizes. He pools the 1984 and 1985 panels of the SIPP which yields 533 spells of welfare receipt for female heads of household. With this sample, he includes 88 local area effects along with the labor market variables.

While the evidence from the welfare spell literature is inconclusive, related studies suggest that labor market conditions may be important for welfare recipients. Labor market variables are significantly correlated with changes in the size of the AFDC caseload. As reviewed by Peskin (1993), most of these studies look at the national caseload or the caseload in a particular state and very few studies pool statelevel caseload data. Peskin finds that the elasticity of the AFDC caseload with respect to changes in the unemployment rate to be 0.1 and the elasticity of the AFDC-UP caseload to be 0.5 . While these results are encouraging, the use of micro data is preferred to the caseload approach for several reasons. First, the aggregate caseload literature combines the effect of labor market variables on entry into welfare with the effects on the length of spell, conditional on entry. Both for policy purposes and measurement purposes it is important to differentiate between these two components of the caseload. Second, with micro data, one can examine how the sensitivity to changes in labor market conditions varies across demographic groups which may be important for policy purposes. Micro data can also be used to look at recidivism and to examine how labor market variables affect short versus long time recipients. Lastly, and potentially most importantly, the aggregate caseload analysis gives more weight to long spells, leading to an upward bias in the estimated effect if areas with poor economic conditions are more likely to contain persons with a propensity to have longer spells. This is related to the problem of length biased sampling.

Many studies have examined the role that local labor markets play in affecting youth unemployment (Acs and Wissoker, 1991; Cain and Finnie, 1990; Freeman, 1981); racial differences in labor market outcomes (Bound and Holzer, 1993 and 1995); and labor market outcomes more generally (Bartik, 1991 
and 1995; Blanchard and Katz, 1992; Holzer, 1991; Hotz et al, 1995). ${ }^{6}$ These studies almost universally find an important role for local labor market conditions. Another related study shows that local labor market conditions affect the probability of marriage among low income women (Winkler 1994).

\section{Data}

\subsection{LDB Data}

The main data set for this study is the Longitudinal Database of Cases (LDB) compiled by UC Data at the University of California, Berkeley in association with the California Department of Social Services as part of the California Work Pays Demonstration Project (CWPDP). The goal of the project is to document the dynamics of family poverty and welfare use in California (UC Data, 1994). The LDB sample consists of 10 percent of all cases receiving Medi-Cal (California's Medicaid program) for at least one month during the period January 1987 to December 1992. Specifically, the data set consists of a 10 percent sample of all cases ongoing in January 1987 plus a 10 percent sample of all new Medi-Cal cases starting each year from 1987 to the present. A "new" case is one where the person has not received MediCal since January 1987. Operationally "receiving Medi-Cal" means that the individual holds a Medi-Cal card. It is not necessary that they actually receive benefits, just that they are potentially able to do so. This study uses a subset of the LDB, persons receiving AFDC. Because all AFDC recipients are categorically eligible for Medicaid benefits, they should be fully represented in the LDB data. In fact, AFDC cases represent the largest group in the LDB data, accounting for over 30 percent of all cases. Other recipients of Medicaid are the elderly and disabled through Supplemental Security Income (SSI) program and AFDCMedically Needy recipients, each accounting for about 20 percent of the LDB cases.

The LDB data is compiled from administrative records and contain monthly recipiency information from the time the case is first observed through the end of 1992. Each person in the sample is followed

This literature is quite large and this is not meant to be a comprehensive review. I have cited the studies most relevant for this analysis. 
throughout the sample period. If a person leaves welfare in 1990 then returns in 1992, both the earlier and later spell are observable. There are 97 different aid codes provided for each month of recipiency and AFDC cases are easily identified from this information. The AFDC aid codes which are identified include: single parent families with children (AFDC-FG or Family Group), two parent families with children (AFDC-UP), AFDC refugee assistance, AFDC assistance for pregnant mothers, and AFDC for foster children. ${ }^{?}$

Characteristics of the family that are contained in the data include: age, race/ethnicity and gender of parent(s), number, ages, and race/ethnicity of each of the children in the case, AFDC recipiency status, and residential location. The ethnicity variable identifies white, black, Hispanic, as well as eight Asian groups, Native Americans, and Pacific Islanders. ${ }^{8}$

This data set is uniquely suited for this analysis for a number of reasons. First, the sample size is large comprising over 100,000 AFDC cases. This allows for the identification of important subgroups of recipients including two parent families receiving AFDC-UP, and different racial/ethnic groups such as blacks, Hispanics, and southeast Asians. Second, the data set contains information on the county, public use micro data areas (PUMA), SMSA, and zip code of residence. ${ }^{9}$ Third, because the data set is based on administrative data, the spells are accurately measured, without recall error. ${ }^{10}$ The data allow for the identification of monthly spells, while the PSID (the major data set used in this area) captures annual

There are several other data sets that will eventually be released as part of the CWPDP. These include annual interviews with a small subsample to collect information on labor market connection, family composition changes, income, and other demographic variables. These efforts will result in a data set that includes all the strengths of administrative data (accurate spells, relatively large sample sizes) along with the benefits of household survey data (lots of control variables). There are also plans to match to state level UI and IRS databases to collect employment information.

"While Hispanics can be of any race, separate race and ethnicity variables are not provided on the LDB. The data is assigned by the case worker.

The public use version of the data identifies the all PUMAs and all counties with 100,000 residents or more. In addition I was given access to the full set of county identifiers and the zip code data.

${ }^{10}$ There is some evidence of seaming in the LDB data. That is, a disproportionate number of spells end in December, and to a lesser extent, begin in January. California Department of Social Service analysts suggest that this is a result of county record keeping procedures. 
welfare spells." As is well known, given that eligibility for AFDC is determined on a monthly basis, the use of annual data can create significant measurement error, or time aggregation, problems. Finally, data from California provide an excellent sample to use for this study. Califomia contains over 15 percent of the nation's AFDC caseload, more than twice the size of the next largest state (U.S. House of Representatives, 1994). Furthermore, the state's caseload is unique in terms of the its racial and ethnic diversity and its sizeable AFDC-UP caseload. Lastly, the time period covered by the data set includes a period of economic expansion and falling unemployment rates (1987-1990) followed by a recession with rising unemployment rates (1990-1992).

The data set, however, has some important limitations. Because it is based on administrative data, the demographic information for the recipients is limited. For example, marital status and education are important determinants of length of time on welfare, but are not available in the LDB data ${ }^{12}$ The approach for obtaining unbiased estimates in the presence of these omitted variables is discussed below. Second, the survey is a sample of Medi-Cal recipiency not AFDC receipt. If a woman starts receiving AFDC, but is never issued a Medi-Cal card, she would never appear in the sample. This problem is not likely to be severe since the participation rate in Medicaid among AFDC recipients is over 97 percent (US House of Representatives, 1994). According to state welfare analysts, application for Medi-Cal usually is done at the same time application of AFDC is started. Lastly, people moving out of state are lost entirely and can not be differentiated from people ending a welfare spell.

The monthly welfare receipt information is used to construct information on spells. Welfare spells are defined to be a period of continuous AFDC receipt. However, interruptions of one month are ignored

\footnotetext{
"The SIPP allows for monthly spells but it suffers from seaming problems (Blank and Ruggles 1996) and a relatively short -32 month - survey period. The NLSY allows for monthly spells but is only valid for the young cohort that it covers. Since 1984, the PSID has collected monthly AFDC participation information. This is retrospective data and is collected at annual interviews

${ }^{12}$ As mentioned above, data for a subsample of the LDB data set (1,000 cases in four counties) has been supplemented with extensive demographic data obtained from household interviews. This will be used to examine the sensitivity of the results to the excluded covariates.
} 
in the construction of spells. ${ }^{13}$ As is typical with panel data, the welfare spells in the LDB data can be left or right censored. A left censored spell is one in which the individual is observed to be on welfare in the first period of the sample (January 1987) while a right censored spell is one in which the individual is still on welfare when last observed (December 1992). All left censored spells are dropped from the analysis since one is unable to determine how long the individual has been on welfare, and therefore unable to control for duration effects in the model. ${ }^{14}$ The remaining data cover all new spells started after January 1987, covering a period of 71 months. Using this data, we construct a sample of all spells in the data set, including repeat spells. Recidivism is quite common among AFDC participants and about one half of the cases in our sample have more than one spell. The model outlined in the next section treats each spell independently. In future work, this assumption may be relaxed. ${ }^{15}$

This sample consists of about 250,000 AFDC spells which results in about 4 million monthly transitions (the unit of observation for the discrete duration model). Because of the large sample size, the results presented here use a 1 percent sample of all Medi-Cal recipients, also released by UC Data. The 1 percent sample contains a total of 23,560 AFDC spells. The final sample is obtained after dropping all left censored spells, cases with no children, UP cases without two parents, and FG cases without any parent, cases where the parents are older than age 55, and cases with miscoded race data. Parents over age 54 were dropped because employment is less likely to be an option for them. After the sample selection, there remain a total of 12,221 AFDC spells, or 191,294 monthly transitions. ${ }^{16}$ About 7,100 are

\footnotetext{
${ }^{13}$ According to discussions with county welfare administrators, the majority of spell disruptions of one month are due to recipients' delay in submitting routine eligibility forms.

${ }^{14} \mathrm{An}$ alternative is to use distributional assumptions to integrate out the welfare history for the left censored observation as described by Heckman (1981).

${ }^{15}$ Ignoring multiple spells may reduce the efficiency of the results, but for the purposes of the question posed here, it makes sense to treat spells individually as opposed to constructing some sort of multiple spell model. Examining recidivism is very important and interesting, but is being left to future work when the welfare utilization data is merged with individual earnings data.

${ }^{16}$ Dropping left censored spells and "child only" cases (no parent in the recipiency unit) account for most of the sample reduction. 5,783 spells are left censored; 4,670 spells are child-only; 1,181 UP spells have only one parent; about 400 cases have parents older than 54; 50 have no children; and 10 have improper race codes. Child only cases are quite common in California, accounting for about 20 percent of all AFDC cases (California DSS,
} 
first spells and 3,600 are second spells.

\subsection{Local Labor Market Variables}

Local labor market variables are assigned to each recipient in each month they are on welfare based on their county of residence. I consider several altemative labor market variables including unemployment rates, employment, employment to population ratios, average earnings and the industrial composition of employment. All employment and earnings data come from quarterly UI reports known as 202 data. The 202 data are establishment data, based on a large sample of employers in various industries, and provide county level employment and earnings figures by 1-digit SIC code on a quarterly basis. This is used to construct a time series of county level employment (total and by sector), average earnings (total and by sector), and employment to population ratios. Average quarterly earnings are constructed by dividing total quarterly payroll by quarterly employment. This is not a wage measure, but instead reflects expected earnings conditional on obtaining a job. The eamings variable will increase when tumover is low and hours are high. Industrial composition is constructed by dividing l-digit level industrial employment by total employment. Employment to population ratios use annual county population figures, which are interpolated between decennial census years. The empirical work will explore the importance of wages and employment by industry with a focus on the retail trade and service sectors, as they are more likely to employ the relatively low-skilled welfare participants (Brandon 1995).

Most studies have used unemployment rates as a measure of labor market opportunities, and I consider them here as well. Unemployment rates at the county level are available monthly but must be estimated using an imputation procedure known as the "handbook method" (Bureau of Labor Statistics, 1992). Several different data sources are used to construct these unemployment rates for counties including the Current Population Survey, UI data on insured unemployment, and other establishment level

1994). The most common reason for this is that the parent(s) is undocumented. Because these parents are not in the aid group, I do not have any information about them. This is also the reason for dropping UP cases with only one parent. Pregnant women with no other children were not dropped as these women are eligible for AFDC in the last trimester of their pregnancy. 
survey. As discussed by Bartik (1995), because of its reliance on multiple data sets, the unemployment rates may be subject to significant measurement error. This could be particularly troublesome when the estimates are identified using cross county differences in the trends of labor market conditions as is the case when county and time effects are included. Furthermore, movements in the unemployment rate are affected by fluctuations in labor supply through changes in the labor force participation rate. This is less likely to be the case with employment based measures. For both reasons, employment based measures are preferable to unemployment based measures.

Critical to the study is sufficient variation in labor market conditions both across areas and over time. Within the state, there is significant variation in the labor market conditions. For example, in June 1991, unemployment rates varied from relatively low levels in northern urban areas $(6.1 \%$ for Oakland, $5.4 \%$ for San Francisco), to moderate levels in the southern urban areas (8.5\% in Los Angeles), to very high levels in the rural areas (12.2\% in Fresno). Figure 1 shows unemployment rates by county for a few large and illustrative counties. LA county accounts for about 35 percent of the states' total AFDC caseload, while the other counties represented in the graph each account for 5-8 percent of the state caseload. The recession hit sooner and harder in southern California. Unemployment rates in the northern urban areas are generally lower than those found in the south throughout the period. Fresno county is an important agricultural county in the state, and has the largest caseload outside the major urban areas. Unemployment is much higher in these areas and is much more seasonal, reflecting the importance of the agricultural sector. This variation will be important for the identification of local labor market effects. ${ }^{17}$

\subsection{Neighborhood Variables and Other County Variables}

Because of limited demographic variables, I augment the LDB data by controlling for the characteristics of the neighborhood in which the family resides. The neighborhood variables are measured at the zip code level and are constructed from the 1990 Census summary files. These effects are assumed

\footnotetext{
${ }^{17}$ In some cases the relevant labor market area may be larger or smaller than the county. While sub-county data is, in general, not available, using MSAs for labor market areas did not change the results significantly.
} 
to be constant throughout the spell since they are measured at a single point in time. Variables examined include poverty rates, median household income, high school completion rates, employment rates for men and women, percent of families headed by single women, urban composition, and percent of women never married. Many of these variables are also tabulated by race and ethnicity. In practice, these variables were found to be highly collinear, and only a subset are used in the estimates. The literature on neighborhood effects, as reviewed by Jencks and Mayer (1990), provides evidence that zip code or census tract areas are preferred to county, PUMA, or SMSA areas. There are a total of 1,106 zip codes represented in the data, or about 26 per county. ${ }^{18}$

Resources spent on job training and education may vary significantly across counties. Accordingly, the empirical work also includes measures of participation and cost of the Greater Avenues for Independence (GAIN) program. California's GAIN program is the nation's first and largest welfare to work program and stresses education, basic skills, training, and job search. The GAIN data is available annually and is used to construct two variables, county participation rate and expenditures per GAIN participant.

\section{Model}

The length of time that an individual receives welfare can be thought of as the outcome of a dynamic optimization process, where the individual compares utility on and off welfare at each point in time. This should take into account not only current income (and utility) on and off welfare, but expectations about future income given the participation decision made today. Primary routes off welfare include labor market success (either increasing hours or getting a new job), and, for female heads of household, marriage. A standard implication of dynamic utility based models is that increases in resources available on welfare (e.g. welfare benefits) lead to longer welfare spells while increases in resources off

${ }^{18} \mathrm{Zip}$ codes represent a relatively small geographic area. While census tracts contain about 4,000 to 5,000 persons, zip code areas in California average about 10-20 times the size of a census tract. They are smaller than PUMAs, which contain at least 100,000 persons, and MSAs. 
welfare (e.g. higher wages, higher likelihood of jobs, greater marriage opportunities, stronger labor market conditions) lead to shorter welfare spells. Thus, local labor market conditions naturally enter the problem through changing current as well as future earnings prospects for the parent(s) in AFDC families as well as the potential spouses of the female headed recipients. Therefore we would expect that increases in employment and decreases in unemployment rates, though increasing the probability of job market success, and increases in real earnings, through increases in the returns to working, will decrease the length of welfare spells. Models of welfare participation also incorporate the "costs" of participating in the program which can include time and money costs of application as well as the "stigma" or distaste of welfare participation. These costs were introduced as an explanation for the fact that the take-up rate for AFDC is far less than 100 percent (Moffitt 1983).

\section{Empirical Model}

The determinants of welfare spells are estimated using a discrete time hazard model. ${ }^{19}$ The basic element of a duration model is the hazard or exit rate $P(t, Z)$, which captures the probability of leaving AFDC in the $t$ th period given continuous welfare receipt for the last $t-I$ periods and covariates $Z$. The hazard rate is used to construct two other distributions of interest: the duration distribution and the survivor function. The duration distribution $f(t, Z)$ characterizes the likelihood that an individual experiences $t$ periods of continuous AFDC receipt and the survivor function $F(t, Z)$ depicts the probability that an individual will experience a welfare spell that lasts at least $t$ periods. ${ }^{20}$ Both distributions are conditional on covariates $Z$ and on initial entry onto welfare. The probability of observing an uncensored spell of length $T$ is the duration distribution and the probability of observing a right censored spell is the survivor

\footnotetext{
${ }^{19} \mathrm{An}$ introduction to duration models can be found in Heckman and Singer (1984), Kalbfleisch and Prentice (1980), and Lancaster (1990).

${ }^{2}$ Once a form for the hazard rate is specified, one can construct the estimates for the duration distribution and survivor function using the properties of conditional probabilities. In the discrete case, the hazard rate, duration distribution and survivor function are linked by $f(t)=S(t-1) P(t)$ and $S(t)=\prod_{\tau=1}^{t}[1-P(\tau-1)]$.
} 
function. Thus, given functional form assumptions, the likelihood function for the sample is,

$$
L(T, Z)=\prod_{i=1}^{N} f\left(T_{i}, Z_{i}\right)^{1-\delta_{i}} F\left(T_{i}, Z_{i}\right)^{\delta_{i}}
$$

where the indicator variable $\delta_{\mathrm{i}}$ is equal to one if the spell is right censored.

Given a specification for the exit probability, the model is easily estimated using conventional maximum likelihood methods. Suppose we specify the exit probability is a function of the available demographic variables and the time varying local labor market variables. Estimates of the labor market variables from this model may be biased for several reasons. First, there are omitted individual characteristics that may be correlated with the labor market variables. For example, suppose that persons with low education levels and poor employment prospects are more likely to be located in areas with adverse economic conditions. Even if there was no relationship between welfare spells and local economic conditions, the estimates would imply an effect. While this omitted variable bias is present to a certain extent in all studies of local labor markets, it may be particularly problematic in this application due to the limited number of variables in the administrative data. In order to address this problem, as well as that of omitted county characteristics, we include both county level fixed effects and the zip code level neighborhood variables. Second, the family's residence may be endogenously determined. If no family moves during the sample then the county level effects will also eliminate this potential problem. However, families do move and if families move in response to changes in labor market conditions, then the estimates will be biased. For example, suppose families anticipating a long spell move out of their expanding labor market in response to higher costs of living. If they move to an area with worse economic conditions then our estimates will, as above, be biased upwards. In an extension to the main results we use the family's county of residence at the beginning of the spell to assign labor market variables. Third, the composition of the welfare caseload may change over the business cycle. When times are bad, we would expect that the marginal new entrant will have more education and experience than those joining the rolls during good times. If that is true, then it will act to dampen the estimated effects. Lastly, the LDB data does not 
identify what happens to welfare recipients when they leave AFDC. Many of the recipients are undoubtedly leaving for reasons other than labor market transitions. The estimated effects on earnings exits will be larger than those estimated here. ${ }^{21}$

In the empirical work, the exit probability is modeled as a logit probability:

$$
P(t, Z)=\frac{\exp \left(\alpha_{i}+Z_{i t} \gamma\right)}{1+\exp \left(\alpha_{t}+Z_{i t} \gamma\right)} .
$$

The $\alpha_{t}$ are dummy variables for length of the spell to date, accounting for the basic duration properties of the model. This non-parametric specification for the duration effects is very flexible and can easily be implemented with the data set. To implement the specifications in the discussion above, the vector $Z_{i t}$ contains individual covariates, labor market variables, neighborhood variables, local area fixed effects, and time effects. To control for the generosity of the welfare system, the regressions also include the combined value of AFDC and Food Stamps benefits. This variable only varies over time, however, and can not be identified with time effects in the model. ${ }^{22}$

The logit specification has been used often in the literature (Bane and Ellwood, 1983; Ellwood, 1986; Fitzgerald, 1994 and 1995; and Hoynes and MaCurdy, 1993 and 1994) and is attractive because it allows for time-varying covariates, a flexible form for the effect of time on welfare on exits, and is relatively easy to estimate. ${ }^{23}$ The specification also easily allows for interactions between the duration

\footnotetext{
${ }^{21}$ Dropping left censored spells will likely lead to an upward bias in the labor market effects. In this case, the results should be interpreted as the effects on new entrants. In addition, if those moving out of state come from the worst labor markets, the estimates may be an underestimate. Manski's example of a spurious relationship between labor market variables and outcome variables (Manski 1993) is not likely to hold here since welfare recipients represent a small fraction of the potential labor force and not all recipients enter the labor force when they leave welfare.

${ }^{2}$ The combined benefit from AFDC and Food Stamps is equal to $70 \%$ of the maximum AFDC benefit plus the Food Stamp maximum benefit reflecting the fact that AFDC income is taxed in calculating the Food Stamp benefit. AFDC benefits are set at the state level and do not vary within California. Food stamps are federally set.

${ }^{23}$ Alternatively, Blank (1989), Fitzgerald $(1992)$, and O'Neill et al $(1984,1987)$ use continuous models to analyze welfare spells. Fitzgerald $(1992)$ and O'Neill et al $(1984,1987)$ use a complementary log-log specification which results from aggregating the continuous proportional hazard into discrete intervals. Both the discrete and continuous approaches easily allow for time varying covariates and including unobserved heterogeneity. The discrete approach generally has a computational advantage.
} 
effects and the economic determinants of welfare spells. The duration effects $\alpha_{t}$ determine how the exit probability changes over the spell and the covariates $Z$ act to scale the exit probabilities up or down uniformly.

\section{Descriptive Analysis}

Table 1 compares the distribution of spell lengths in our LDB sample to estimates from other studies using monthly data. The table compares estimates of the probability that a spell lasts at least 6,12 , and 24 months. Each of these are non-parametric(Kaplan-Meier) estimates and do not control for any covariates. The first row shows that 72 percent of AFDC spells in the LDB data last 6 months or more, and 36 percent last 2 years or more. This data is fairly consistent with the other studies using monthly welfare participation data (Fitzgerald, 1995; Blank and Ruggles, 1996; Gritz and MaCurdy, 1992, Harris 1993). The Gritz and MaCurdy estimates imply longer spells but they are based no a sample of youths, a group who typically have longer spells. The LDB data shows somewhat longer spell lengths compared to the SIPP which may be due to California's relatively high AFDC benefits and differences in the composition of the AFDC population.

To explore the differences in spells for demographic groups, Table 2 presents estimates of the distribution of length of AFDC spell for families with various characteristics. The table presents the probability that a spell lasts less than or equal to 6 months, 1 year, 2 years and 4 years. Like the estimates in table 1, these are non-parametric and do not control for any covariates. Overall, 28 percent of spells last 6 months or less, while 38 last more than 2 years. AFDC-UP spells are somewhat shorter than single parent AFDC spells. While 49 percent of AFDC-UP spells end within 1 year, only 45 percent of AFDC-FG spells end in that period. There are striking differences in the length of spells for different racial groups. 31 percent of spells end within 6 months for whites, compared to 23 percent among Blacks, and 28 percent among Hispanics. Furthermore, teen parents and families living in urban areas have longer spells than older parents living in non-urban areas. 
To explore the relationship between local labor market conditions and the length of time on welfare, Figures $2 \mathrm{a}$ and $2 \mathrm{~b}$ plot the probabilities that a spell lasts a year or less against average labor market conditions for each of the 58 counties in California. ${ }^{24}$ Figure $2 \mathrm{a}$ uses unemployment rates and Figure $2 \mathrm{~b}$ uses employment to population ratios. The points are weighted by the size of the county, with larger circles representing larger counties. The general pattern provides support that stronger labor markets (lower unemployment rates, higher employment to population ratios) are associated with shorter spells. The figures also show that California's larger, more urban counties tend to have stronger labor markets than the smaller, more rural counties.

Figure 3 shows the empirical hazard rate for leaving welfare. The circles indicate the estimate of the hazard rate and the vertical line indicates the 95 percent confidence interval around the estimate. After rising for the first few months, the hazard declines throughout the spell. This is consistent with other studies.

Tables 3 and 4 present descriptive statistics on the estimation data set. Table 3 presents means of all variables that are constant over the spell. About one third of the spells are right censored which is mostly accounted for by spells starting in the last two years of the sample. Spell lengths average 12 months for uncensored spells and 24 months for right censored spells. About 15 percent of the spells are AFDCUP spells. The MALEHEAD variable is defined as equal to 1 if the family is a headed by a single male (e.g. and not a UP recipient). The PREGNANT variable is defined as equal to 1 if the woman is pregnant with no other children in the household at the beginning of the spell. ${ }^{25}$ PREGNANT along with the dummies for age of the youngest child are exhaustive and mutually exclusive.

Table 4 presents the descriptive statistics for variables that vary over the spell. There is one observation for each of the monthly transitions in the data. The unemployment rate averages 7.5 percent

\footnotetext{
${ }^{24}$ The "average" unemployment rate is constructed as a weighted average of each period's rate, using the caseload as the weight. The same is done for average employment to population ratios.

${ }^{25}$ This is verified by the birth of a child in the first 3-4 months of the spell.
} 
over the period while average quarterly wages are 6,699 dollars. All earnings variables are in 1992 dollars. The employment to population ratio averages 0.40 . The composition of employment is captured by the nine employment by sector variables. Overall, services are the largest sector, followed by retail trade and manufacturing.

The neighborhood characteristics and GAIN variables are summarized at the bottom of the table. ${ }^{26}$ Urban-Inside is equal to one if, based on their zip code of residence, the family resides in an urbanized area while the Urban-Outside variable is one if the family lives in an urban area, but outside the urbanized area. 86 percent of AFDC cases reside in urbanized areas while only 4 percent reside in rural areas. MEDHINC is the median household income and FEMNVMAR is the percent of women over age 18 who are never married. The GAIN participation rate is the number of participants divided by the number of AFDC adults. The second GAIN variable is the average GAIN expenditures per GAIN participant, which reflects the intensity of the program.

\section{Results}

\subsection{All Demographic Groups}

Table 5 presents the initial estimates from the discrete duration model before adding any labor market variables. The first specification in table 5 includes dummies for spell duration (to control for duration effects), the AFDC\&FO guarantee, and family demographic characteristics such as age of head, number and ages of children, AFDC eligibility type, and race/ethnicity. The demographic variables are set as of the beginning of the spell and are not time varying. ${ }^{27}$ Duration dummies for single month are provided for the first 12 months in the spell, followed by dummies for 3 month periods for the next 2 years, followed by dummies for 6 month periods for the last 3 years. This model was selected after extensive

\footnotetext{
${ }^{20}$ Some cases in the LDB data were missing zip codes. 11,458 of the 12,221 spells have a valid zip code.

${ }^{27}$ The only individual characteristics that are time varying are the number and ages of children. Because of the potential endogeneity of fertility outcomes, these variables are fixed as of the beginning of the spell.
} 
testing using conventional testing methods. The duration effects from the logit model, not shown here, show the same pattem as the unconditional hazard in Figure 3. The probability of exiting welfare rises for the first few months, then declines steadily throughout the length of the spell. These duration dummies are jointly significant at the 1 percent level in all specifications. The individual significance of the dummies is strong through spell lengths of three years, but the standard error is quite large for the last few periods. The dependent variable is an exit from welfare. Therefore, a positive coefficient implies that an increase in the covariate leads to higher exit probabilities and shorter spells.

These results show that longer spells are found for younger mothers, with more children, and with younger children. Single parent families headed by men tend to have shorter spells than those headed by women. This may be due to better labor market opportunities that are not being controlled for in the regression. These results also show significant differences by race. Hispanics and blacks both have longer spells than whites, with blacks having the longest spells. This is consistent with analyses of young women on welfare using the NLSY (Gritz and MaCurdy, 1992). Cambodians, Laotians, and Vietnamese are found to have dramatically longer spells than any other racial group. Most AFDC recipients from these countries are recent immigrants with current or previous refugee status. The groups are generally thought to have longer spells than native bom individuals due to limited English proficiency and labor market skills. ${ }^{28}$ The coefficient on AFDC\&FO has the wrong sign, implying that increases in welfare benefits lead to shorter spells. This variable, however, exhibits only time variation and may be proxying for other trends in the state. Once the time effects are added to the regression, the benefit variable is not identified and is dropped from the regression.

The second specification in table 5 adds controls for selected county and neighborhood variables. The neighborhood variables, assigned by zip code using the 1990 Census, are included as crude controls

\footnotetext{
${ }^{28}$ Upon arrival to the US, refugees are immediately enrolled in public assistance programs, and the conditions to maintain eligibility are more lenient than with other AFDC participants. This may also contribute to their longer spells. California has a large number of refugees relative to other states. The main results of the paper hold when persons in these racial groups are dropped from the sample.
} 
for omitted individual characteristics such as education, prior labor market experience, and marital status, all of which are important predictors of welfare dependency (Bane and Ellwood 1983) and may also be correlated with the labor market variables. For example, it is possible that "bad" neighborhoods as captured by high poverty rates and low education levels are more likely to be located in areas with depressed labor markets. By omitting neighborhood effects, one would get a biased estimate of the role of labor markets in welfare dependency. ${ }^{29}$ Because of the limited number of individual covariates available in the data, the coefficients on the neighborhood variables should not be interpreted as "neighborhood effects". ${ }^{30}$ The estimates in (2) show that persons living in urban areas, with lower median household income, and with more never married women have longer AFDC spells. ${ }^{31}$ Adding these neighborhood variables dramatically reduces the differences between whites, Hispanics, and blacks, resulting in no significant differences between Hispanics and whites.

Model (2) in Table 5 also shows that higher GAIN participation is associated with shorter spells and higher GAIN expenditures per participant with longer spells. Interpreting this as a pure program effect would suggest that GAIN is successful at moving participants from welfare to work. Higher GAIN expenditures may be a result of more intensive training programs which may delay employment. The evaluation of the GAIN program supports these interpretations (Riccio et al, 1994).

\footnotetext{
${ }^{29}$ The implication of omitting important individual covariates can also be addressed by allowing for unobserved heterogeneity such as in Blank (1989). Fitzgerald (1994) finds that adding unobserved heterogeneity does not change the importance of the labor market effects. Further, the importance of unobserved heterogeneity has been found to be small when a flexible form for duration effects is included (Meyer 1990).

${ }^{30}$ It is difficult empirically to separately identify effects that operate through one's own background characteristics compared to the effects that operate though the characteristics of one's local area (neighborhood effects). In this study, the prevalence of omitted individual characteristics makes the interpretation even more difficult. In addition, the neighborhood variables are assigned based on the current residence for the individual. Given the emphasis in the literature on schools and other institutional features, the neighborhood where one was raised may also be important. The difficulties associated with identifying neighborhood and family effects is well recognized in the literature and is discussed at length by Jencks and Mayer (1990).

${ }^{31}$ In addition to the variables presented in model (2), race specific high school graduation rates, poverty rates, and employment rates were examined. The neighborhood variables are highly collinear so only a subset are presented. Many alternative specifications were estimated and the results are not sensitive to the particular specification presented here.
} 
Table 6 explores the economic significance of the covariates by presenting selected characteristics of the estimated spell durations for alternative values for the covariates using the estimates of model (2) in Table 5. The table includes estimates of the probability the spell is completed in less than 6 months, 12 months, 2 years, and 4 years. The first row of Table 6 gives the predicted values for the spell distribution using baseline characteristics (described in the table). The largest effects are found for race of the head, age of the youngest child, and gender of the head. For example, only 39 percent of spells for pregnant women without any other children end within one year compared to 55 percent of spells where the youngest child is over age 6. Because the existence of pregnancy benefits is not particularly well known, this large difference for first time pregnancies may reflect unobserved differences concerning the propensity to have a long spell. Single parent families headed by men are 24 percent more likely to complete a spell within a year compared to female headed households. Black families and teen parents are both 10 percent less likely to complete spells within one year. Individuals in rural areas have the shortest spells while those living inside urbanized areas have the longest spells. The other neighborhood variables and GAIN variables are statistically significant but have fairly small impacts on the length of the welfare spell.

\section{Results Based on Unemployment Rates}

To begin the examination of labor market variables, let us consider the effects of unemployment rates and wages on the length of welfare spells. I have argued above that employer based data is preferable to unemployment rates but I start with unemployment rates in order to compare my results to those in the literature. The results using average wages and unemployment rate are provided in table $7 .^{32}$ The first specification does not include county or time effects and shows that the county unemployment rate has a negative and significant effect on welfare spells implying that higher unemployment rates lead to longer spells. Higher earnings are associated with longer spells, which (although insignificant) is the opposite of what theory would predict. Because of many omitted county variables, it is not clear how to interpret this

\footnotetext{
${ }^{32}$ This table and the remaining tables of estimates suppresses all covariates except the labor market variables. The full set of estimates is available from the author.
} 
coefficient. For example, higher earnings may reflect a higher skilled employment base which may not be accessible to the average welfare participant. In order to control for the differences between the counties, specification (2) includes county fixed effects for the 58 Califomia counties. Comparing the results to those in (1), adding county fixed effects turns the coefficient on average earnings from negative and insignificant to positive and significant and increases the magnitude of the unemployment effect by about 20 percent. ${ }^{33}$ Thus, in contrast to the results in Fitzgerald (1994), adding the county fixed effects make the results stronger!

I suggested above that one reason that this approach is preferred over the caseload approach is that one can control for duration effects. In order to examine the significance of including duration dummies, I ran a specification that included only the unemployment rate, earnings, and a constant term. In those results (not shown here) the coefficient on the unemployment rate was about 50 percent larger than that presented in (1). This upward bias results from the fact that persons living in areas with higher unemployment rates have, on average, longer spells.

Returning to the results in Table 7, with county fixed effects the results are identified from within county changes in unemployment rates and wages. If there was some factor, such as a change in state policy conceming poor families, that affected all counties in the state and was correlated with the state's local labor market conditions then these estimates would be biased. ${ }^{34}$ In order to address this possible bias, the third column of Table 7 adds period dummies to the model. This has no impact on the wages but renders the unemployment rate small and insignificant. There are at least two explanations for this result. The first is that the unemployment rate is measured with a lot of error. Once county and time effects are added, what remains is mostly noise. The second is that there is not enough variation in the trends in local

\footnotetext{
${ }^{33}$ In results not shown here, adding controls for the percent distribution of employment by sector (1-digit SIC) also reverses the sign on quarterly wages. While somewhat difficult to interpret, these variables may control for differences in the skill composition of the labor market. These measures do not exhibit much time series variation and are measured very imprecisely after county fixed effects are included.

${ }^{34}$ Examples include an increase in the state minimum wage and reductions in state AFDC benefits.
} 
labor market conditions across the counties to separately identify county, time and labor market effects. As we will see below, the alternative measures of job opportunities are robust to including time effects. For this reason, and because and imputation procedure is necessary to construct county level unemployment rate series, measurement error is the more likely explanation. ${ }^{35}$

In specifications (4) and (5), the average earnings variable is replaced by average earnings in services and average earnings in retail trade. Earnings in services prove to be important for welfare recipients, but surprisingly, eamings in retail trade are not statistically significant. This result is quite robust and holds for alternative controls for job availability and holds in the absence of the period effects. An analysis of variance shows that retail earnings vary less over time than service earnings which may explain this result. As we will see below, retail sector employment growth is important.

\section{Results Based on Employment}

Table 8 presents estimates which replace the unemployment rate with the log of employment in the county. Each of the specifications in the table include county fixed effects. Accordingly, the coefficient on $\log$ employment captures the effects of employment growth on the probability of leaving welfare. ${ }^{36}$ The table shows that in each specification, higher employment and wage growth lead to significantly shorter spells. These estimates are virtually unchanged by the inclusion of period effects, shown in column 2 . The last two columns of Table 8 replace the log of county employment with the log of service employment (model 3) and retail trade (model 4). This shows that higher growth in retail trade and service employment lead to shorter spells.

Results Based on Employment to Population Ratio

\footnotetext{
${ }^{15} \mathrm{~A}$ risk of estimating heavily saturated models such as this one (including time and county effects) is that the controls will absorb some of the effects of interest. For example, suppose that county labor markets have persistent differences or that there is some common (state) seasonal component to employment patterns. Blanchard and Katz (1992) find that shocks to state labor markets tend to be transitory, disappearing within about 10 years.

${ }^{30}$ Note that adding employment growth directly in the regression, with or without county fixed effects, shows very similar results to those presented here.
} 
The final measure of job availability is the employment to population ratio. The results, presented in Table 9, are qualitatively very similar to log employment regressions. Higher wages and employment to population ratios are associated with significantly shorter spells. Adding time effects reduces the size of the employment to population ratio by about 50 percent, but the wage results remain unchanged. The results in the last two columns shows, consistent with the results in Table 7, that service sector earnings growth but not retail trade growth leads to shorter spells. In general, it is striking how consistent the estimates are for the eamings variables across the different specifications shown in these three tables.

\subsection{Simulated Effects of Changes in Labor Market Variables}

The results in Tables 7-9 suggest that labor market variables play a statistically significant role in determining the length of AFDC spells. However, it is difficult to interpret the magnitude of their impact because of the non-linear specification. Table 10 presents simulations of the effects of changes in labor market variables on the distribution of the length of welfare spells. Each of the seven panels in the table present the simulations for a different specification of the model. The figures in the table show the percent change (relative to the baseline specification) in the probability that a spell is completed within a given time period for a given change in the labor market variable. Each of the simulated changes in the labor market variables represent typical within county changes in the variable observed over the 1987-1992 period. In general, these can be interpreted as variations we might expect between the peak and the trough of a business cycle.

Panel (A) presents estimates from model (2) in table 7 which includes controls for the unemployment rate, quarterly eamings and county fixed effects. The first row of the table shows that a decrease in the unemployment rate of 3 percentage points leads to a 10 percent increase in the probability that a spell lasts 6 months or less, and a 8.6 percent increase in the probability that a spell lasts 1 year or less. In the last column of the table the distribution is summarized by showing the effect on the AFDC caseload assuming that the entry rate into AFDC is constant, and that the effect is permanent. These results show that a 3 percentage point reduction in the unemployment rate would lead to a 10 percent reduction 
in the AFDC caseload and a 5 percent increase in real quarterly eamings would lead to an 8 percent reduction in the caseload. ${ }^{37}$

The next three panels present simulations using the log of employment as the measure of job opportunities, where each specification includes time and county fixed effects. Panel (B) shows that a 10 percent increase in county employment, if permanent, would lead to a 9.7 percent reduction in the caseload A 10 percent increase in service or retail employment show slightly lower reductions in the caseload. The last three panels present simulations using the employment to population ratio. Here a 3.5 percentage point increase in the ratio leads to an 8 percent reduction in the caseload while a 5 percent real increase in earnings leads to a 7.8 percent reduction in the caseload. Panel $(F)$ shows that a 5 percent increase in real service sector earnings leads to a 5 percent reduction in the caseload. These results, and those for employment above, suggest that the service sector is less important for welfare recipients that the industry wide measures. Given that welfare participants are disproportionately represented in the service and retail trade sectors (Brandon 1995), this is somewhat surprising. For comparability, the simulated changes in service and retail trade earnings (and employment) have been set at the same level as that used for the aggregate variable. In most cases, however, services and retail trade grew more than the industry wide variable and using the actual changes result in larger reductions in the caseload than those shown here.

The simulations in Table 10 show that there is a great deal of uniformity in the estimates across the various specifications for the local labor market conditions. On average, a typical fluctuation in job opportunities over a business cycle (from trough to peak), if permanent, would lead to an 8-10 percent reduction in the AFDC caseload. Typical changes in earnings lead to a 7-8 percent reduction in the caseload. These changes can add up to large effects. For example, an increase in employment growth of 10 percent combined with a 5 percent real increase in eamings would lead to a 16.2 percent reduction in

\footnotetext{
${ }^{37}$ Clearly the assumption of constant entry rate is not a valid one. However, this is a convenient way to summarize the effect of changes in labor market variables on the distribution of spells. Assuming that the entry rate was counter cyclical --rising in periods of economic downturns-- the results here would be strengthened.
} 
the AFDC caseload.

\subsection{Results for demographic groups}

Previous research has found significant differences in the responsiveness of different groups of welfare recipients to changes in tax and transfer environment (for a review see Moffitt 1992). Descriptive tables presented earlier also revealed that the average length of welfare spells differs, in some cases substantially, across demographic groups. Accordingly, we may expect to see differences in the responsiveness to labor market conditions, which may be very important for policy purposes. Table 11 presents estimates from regressions which allow for differential effects across various demographic groups, where two regressions are estimated for each group. These specifications are identical to those presented in columns 1 and 2 of Table 9 and include the employment to population ratio and the earnings variable. The first specification includes county effects and the second includes county and time effects. All parameters are allowed to vary, although the table just shows the estimates for the labor market variables. For comparison, the first panel of Table 11 shows the results for all families. The bracketed figures in the table give the percent change in the caseload resulting from a specified change in the labor market variable, as calculated in the last column of table 10 (and the magnitude of the changes in the labor market variables match those presented there).

In general the results with time effects are less precisely estimated, but the coefficients show similar patterns. The second panel shows that AFDC-UP families are more sensitive to labor market conditions than single parent families. This is sensible since AFDC-UP families contain two potential earners, and since they typically have more substantial labor market experience and higher potential wages than single parent recipients (Hoynes, 1996). This is also consistent with the aggregate caseload studies which find greater sensitivity for AFDC-UP caseloads (Peskin 1993). Results not reported in the table suggest that there are other important differences in the determinants of welfare spells for the two groups. For example, while the spells for single parents with pre-school aged children are significantly longer than those with older children, this is not true for UP recipients. This seems sensible since two parent families are more 
able to specialize in home production and labor market participation. Hispanic two parent families have significantly shorter spells than their white counterparts, while Hispanic single parent families tend to stay on welfare longer than white families.

The third panel of Table 11 shows that whites are found to be slightly less (although not significantly less) sensitive to labor market conditions than either blacks or Hispanics. This result is also found in Fitzgerald $(1994,1995)$ and is consistent with the evidence that white women are more likely to leave welfare through marriage and less likely to leave welfare through employment relative to blacks (Bane and Ellwood, 1983; Blank, 1989; Blank and Ruggles, 1996). The results also show that teen parents are not sensitive to changes in job opportunities, perhaps reflecting their lack of work experience and labor force attachment. Residents of urban areas are more sensitive to changes in labor market conditions compared to non-urban groups. ${ }^{38}$

In general, these results are consistent with the literature on the effects of local economic conditions on labor market outcomes of different demographic groups. Bartik (1991) and Bound and Holzer (1995) find larger responses to changes in economic conditions for blacks, less educated workers, and older workers. They argue that this is due to lower migration rates among these groups. When the economy turns down, workers with lower propensities to migrate are hurt more by the downturn relative to those with higher migration propensities. This is an alternative explanation for the greater sensitivity among blacks, Hispanics, and possibly female headed households.

\subsection{Extensions}

The county fixed effects will control for unobserved county factors which are fixed over time. If there are changes over the sample, such as those induced by endogenous location decisions, then the

\footnotetext{
${ }^{38}$ Some of these results are not particularly robust. For example, when the employment to population ratio is replaced by the log of employment, UP families are no longer found to have significantly greater sensitivity. In some specifications, the differences between the racial/ethnic groups is much stronger than those presented here. In general, the large standard errors on many of the estimates is reflected in part by the smaller sample sizes and the difference between groups is not statistically significant. In future work, estimating non-fully interacted models may clear up these inconsistencies.
} 
estimates will be biased. For example, if families who are likely to have long spells move from relatively strong labor markets to relatively weak ones, the estimates will be biased in favor of finding a labor market effect. To address this, we use information on the family's county of residence at the beginning of the spell to assign the labor market variables. This information is used in both a reduced form and instrumental variables estimation procedure. The reduced form model simply assigns the county fixed effect and labor market variables based on county of residence at the beginning of the spell instead of current county of residence. The IV estimates instrument for the current county labor market variables using the labor market variables for the initial county. These results are shown in Table 12. Each of the specifications match that used in model (2) of Table 9 and include employment to population ratio, earnings, county and time effects. These results show that the estimates for employment to population ratio are reduced somewhat but remain statistically significant. The eamings parameter remains unchanged. The robustness to this extension is not surprising since migration rates are fairly low in this population, especially between counties. ${ }^{39}$

I have hypothesized that the average level of job readiness of a welfare entrant will be higher for those entering during bad times compared to good. If this is true, the main estimates will understate the effect of local labor market conditions on welfare spells. In an attempt to control for the composition of the entry population, I included several variables measuring the absolute and relative economic conditions during the period that the spell began. In each of these specifications, the variables were insignificant and the main results did not change.

\section{Conclusion}

${ }^{39}$ Long (1988), in a comprehensive analysis of migration patterns over the past three decades, finds the likelihood of moving within a county to be over 2.5 times more likely than moving across counties (within a state). This difference is particularly striking for public assistance recipients who are 5 times more likely to move within counties than across them. In the LDB sample, about 9 percent of families are observed to move across county lines. The probability of moving is higher for whites, younger heads, and families headed by women. 
This study shows that local labor market conditions have a significant impact on welfare spells for most demographic groups. Minorities, residents of urban areas and two parent families are more sensitive to changes in local labor market conditions. The results are robust to including county fixed effects and time effects. On average, a typical employment fluctuation over the business cycle (from trough to peak), if permanent, would lead to an 8-10 percent decrease in the AFDC caseload. Typical changes in quarterly earnings generate somewhat smaller effects. The combined effect of these two changes, if permanent, would lead to sizeable reductions in the caseload, on the order of 15 percent.

Can economic growth alone eliminate the reliance on public assistance? The results in this paper, I believe, show that the answer is no. Optimistic assumptions about permanent increases in employment and wages reduce but do not eliminate the demand for welfare. However, this is a case of whether the glass is half empty or half full. It is equally important to point out that there is a significant relationship between economic conditions and welfare exits, which contribute to the mounting evidence that employment is an increasingly important route for achieving independence. Thus if time limits for welfare recipients are implemented, then linking them to local labor market conditions may be important.

The impacts in this study may underestimate the true effect of local labor markets on welfare spells for two reasons. First, as mentioned in the introduction, local economic conditions may affect both entry into welfare as well as length of time on welfare conditional on entry. We would expect that, on average, individuals entering welfare during bad times will have higher skill levels and shorter spells than those entering in good times. This factor alone will lead to a negative relationship between economic conditions and spell lengths. Second, this sample does not contain any information about post-welfare employment. Not all those exiting the program are entering employment. A competing risks model, with employment as one of the routes off welfare, would likely show larger labor market effects. Lastly, the earnings measures used in this study are fairly crude, measuring at best variation in the returns to work in 1 digit industry classes. Welfare recipients typically obtain low skilled jobs, and given the relative decline in wages for low wage workers, using a more disaggregate wage measure may show larger effects. 


\section{BIBLIOGRAPHY}

Acs, Gregory and Douglas Wissoker. 1991. "The Impact of Local Labor Markets on the Employment Patterns of Young Inner-City Males." Mimeo, Urban Institute.

Bane, Mary Jo and David T. Ellwood. 1983. "The Dynamics of Dependence: The Routes to Self Sufficiency". Prepared for the U.S. Department of Health and Human Services, Office of the Assistant Secretary for Planning and Evaluation. Cambridge, MA: Urban Systems Research and Engineering, Inc.

Bartik, Timothy J. 1991. Who Benefits from State and Local Economic Development Policies? W.E. Upjohn Institute for Employment Research. Kalamazoo Michigan.

Bartik, Timothy J. 1995. "The Distributional Effects of Local Labor Demand and Industrial Mix." forthcoming, Journal of Urban Economics.

Blanchard, Olivier J. and Lawrence F. Katz. 1992. "Regional Evolutions." Brookings Papers on Economic Activity 1:1992.

Blank, Rebecca. 1989. "Analyzing the Length of Welfare Spells." Journal of Public Economics. 39(3):245-273.

Blank, Rebecca and Patricia Ruggles. 1996. "When Do Women Use AFDC and Food Stamps: The Dynamics of Eligibility versus Participation."The Journal of Human Resources 31(1):57-89..

Brandon, Peter. 1995. "What Happens to Mothers after AFDC?" Focus 17:2(Fall/Winter). University of Wisconsin.

Bound, John and Harry Holzer. 1993. "Industrial Shifts, Skill Levels, and the Labor Market for White and Black Males". The Review of Economics and Statistics, August.

Bound, John and Harry Holzer. 1995. "Structural Changes, Employment Outcomes, and Population Adjustments Among Whites and Blacks: 1980-1990." Institute for Research on Poverty Discussion Paper \# 1057-95.

Cain, Glen and Ross Finnie. 1990. "The Black-White Difference in Youth Employment: Evidence from Demand Side Factors." Journal of Labor Economics 8:S364-95.

California Department of Social Services. 1994. Unpublished memo on child only cases.

Duncan, Greg J. And Saul D. Hoffman. 1990. "Welfare Benefits, Economic Opportunities, and Out-Of -Wedlock Births Among Teenage Girls." Demography 27(4):519-535.

Ellwood, David T. 1986. "Targeting Would-be Long Term Recipients of AFDC". Prepared for the U.S. Department of Health and Human Services, Office of the Assistant Secretary for Planning and Evaluation. Princeton, NJ: Mathematica Policy Research, Inc.

Fitzgerald, John. 1992. "Welfare Durations and the Marriage Market: Evidence from the Survey of 
Income and Program Participation." Journal of Human Resources. 26(3):545-561.

Fitzgerald, John. 1994. "A Hazard Model for Welfare Durations with Unobserved Location-Specific Effects." Mimeo, Bowdoin College.

Fitzgerald, John. 1995. "Local Labor Markets and Local Area Effects on Welfare Duration." Journal of Applied Policy and Management, Winter 1995.

Freeman, Richard. 1981. "Economic Determinants of Geographic and Individual Variation in the Labor Market Position of Young Persons." In The Youth Labor Market Problem: Its nature, Causes, and Consequences, ed. R Freeman and D. Wise. Chicago: University of Chicago Press.

Gritz, Mark and Thomas MaCurdy. 1992. "Transitions from Welfare to Work." Prepared for the U.S. Department of Health and Human Services, Office of the Assistant Secretary for Planning and Evaluation. Mimeo, Stanford University.

Harris, Kathleen. 1993. "Work and Welfare Among Single Women in Poverty," American Journal of Sociology 99(2):317-352.

Heckman, James. 1981. "The Incidental Parameters Problem and the Problem of Initial Conditions in Estimating a Discrete Time-Discrete Data Stochastic Process," in Structural Analysis of Discrete Data with Econometric Applications, eds Charles Manski and Daniel McFadden. Cambridge: MIT Press.

Heckman, James and Burton Singer. 1984. "Econometric Duration Analysis", Journal of Econometrics 24:63-132.

Holzer, Harry J. 1991. "Employment, Unemployment, and Demand Shifts in Local Labor Markets." The Review of Economics and Statistics.

Hotz, V. Joseph, Lixin Xu, Marta Tienda, and Avner Ahituv. 1995. "The Returns to Early Work Experience in the Transition from School to Work for Young Men in the U.S.", mimeo. University of Chicago.

Hoynes, Hilary Williamson. 1996. "Welfare Transfers in Two-Parent Families: Labor Supply and Welfare Participation Under the AFDC-UP Program", Econometrica 64(2):295-332.

Hoynes, Hilary Williamson and Thomas MaCurdy. 1993. "Welfare Spells over the Last Two Decades: Do Changes in Benefits Explain the Trends?". Mimeo, University of California, Berkeley.

Hoynes, Hilary Williamson and Thomas MaCurdy. 1994. "Has the Decline in Benefits Shortened Welfare Spells?" American Economic Review, 84(2).

Jencks, Christopher and Susan Mayer. 1990. "The Social Consequences of Growing Up in a Poor Neighborhood," in L. Lynn and M. McGeary, eds., Inner City Poverty in the United States. Washington D.C.: National Academy Press.

Kalbfleisch, J.D. and R.L. Prentice. 1980. The Statistical Analysis of Failure Time Data. New York: Wiley and Sons. 
Lancaster, Tony. 1990. The Econometric Analysis of Transition Data. Cambridge: Cambridge University Press.

Long, Larry. 1988. Migration and Residential Mobility in the United States. New York: Russell Sage Foundation.

Manski, Charles F. 1993. "Identification of Endogenous Social Effects: The Reflection Problem." Review of EconomicStudies 60:531-542.

Meyer, Bruce. 1990. "Unemployment Insurance, and Unemployment Spells." Econometrica 58(4):757782.

Moffitt, Robert. 1992. "Incentive Effects of the U.S. Welfare System: A Review." Journal of Economic Literature 15(1):1-61.

Moffitt, Robert. 1983. "An Economic Model of Welfare Stigma" American Economic Review 73(5):10231035 .

O'Neill, June A., Douglas A. Wolf, Laurie J. Bassi, and Michael T. Hannan. 1984. "An Analysis of Time on Welfare." Final Report to the U.S. Department of Health and Human Services, Washington, DC: The Urban Institute.

O'Neill, June A., Laurie J. Bassi, and Douglas A. Wolf. 1987. "The Duration of Welfare Spells." Research in Economics and Statistics 69:241-248.

Pavetti, LaDonna. 1993. "The Dynamics of Welfare and Work: Exploring the Process by Which Women Work Their Way Off Welfare." PhD dissertation, Harvard University.

Peskin, Janice. 1993. "Forecasting AFDC Caseloads, With an Emphasis on Economic Factors." CBO Staff Memorandum. July.

Riccio, James, Daniel Friedlander and Stephen Freedman. 1994. GAIN Final Report: Benefits, Costs, and Three-Year Impacts of a Welfare-to-Work Program. Manpower Demonstration Research Corporation.

Sanders, Seth. 1992. "Preliminary Evidence on Human Capital Production and Welfare Participation", Chapter 3 of unpublished PhD dissertation.

Savner, Steve and Mark Greenberg. 1995. The CLASP Guide to Welfare Waivers: 1991-1995. Washington DC: Center for Law and Social Policy.

Sawhill, Isabel (1995). Welfare Reform: An Analysis of the Issues. Washington D.C.: The Urban Institute.

U.S. Bureau of Labor Statistics. 1992. "BLS Handbook of Methods", Bulletin 2414.

U.S. House of Representatives. 1994. Background Materials and Data on Programs Within the Jurisdiction of the Committee on Ways and Means. Washington D.C.: Government Printing 
Office.

UC Data 1994. California Work Pays Demonstration Project: Statewide Longitudinal Database Persons: 1\% Sample, 1987-1992. Mimeo, University of Califomia, Berkeley.

Winkler, Anne. 1994. "The Determinants of A Mother's Choice of Family Structure: Labor Market Conditions, AFDC Policy, or Community Mores?" Mimeo University of Missouri - St. Louis. 
Figure 1

Monthly Unemployment Rates for Selected California Counties, 1987-1992

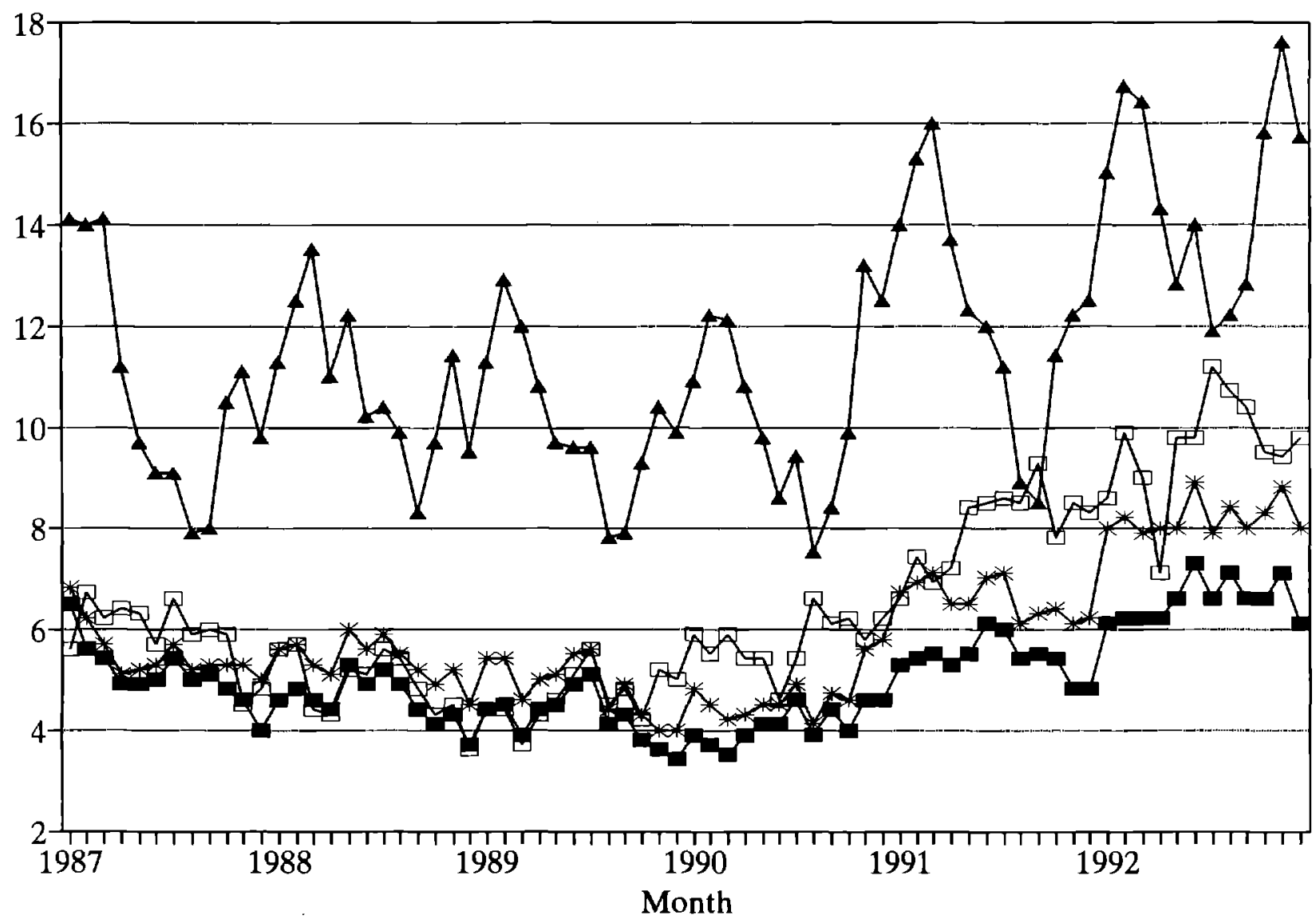

$\rightarrow$ Alameda $\neg$ Fresno $\square$ Los Angeles $\rightarrow$ Sacramento 
Figure 2a

Correlation Between County Level AFDC Spells and Unemployment Aates

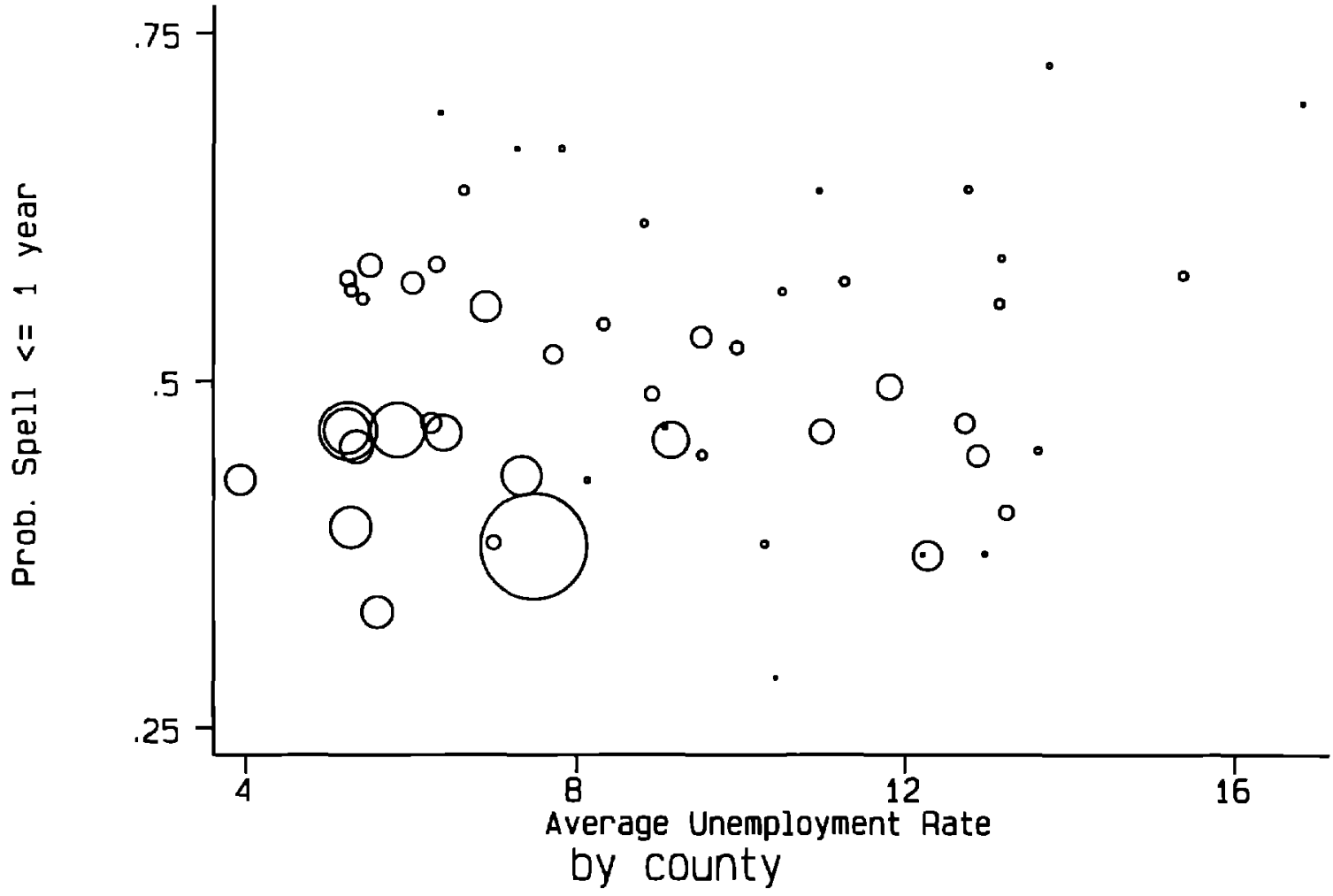

STaTam 
Figure 2b

Correlation Between County Level AFDC Spells and Emp/Pop Aatio

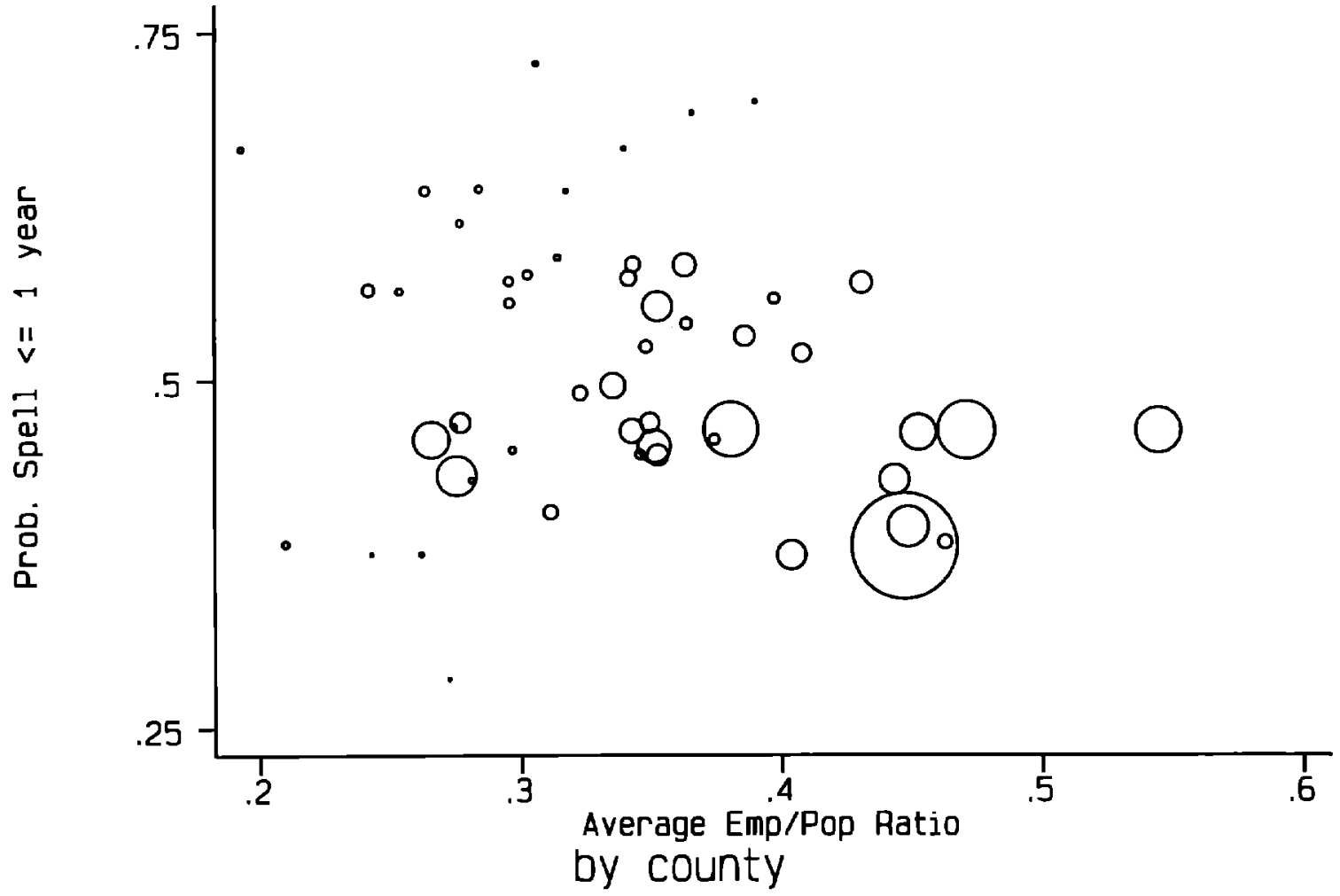

डावाa"m 


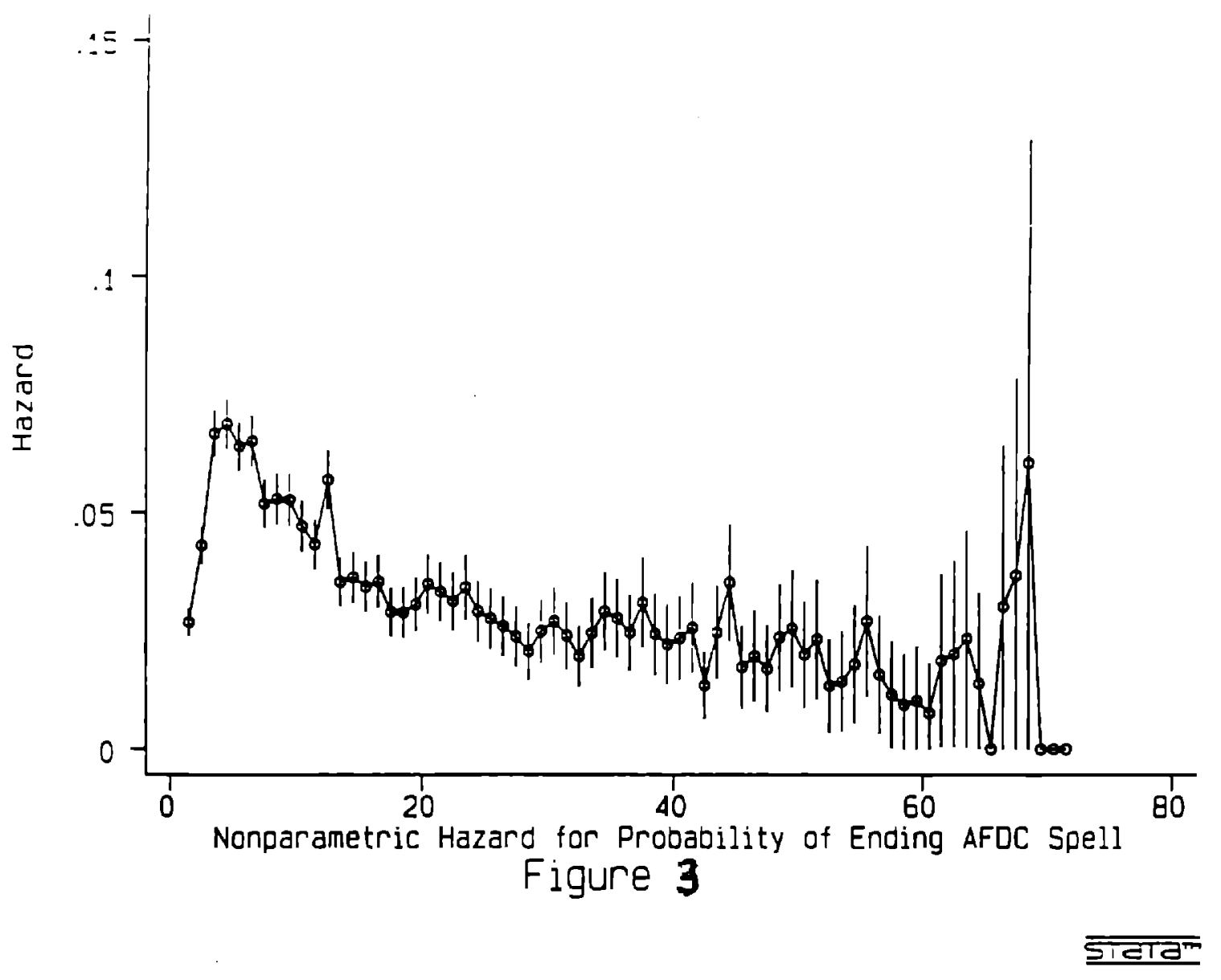


Table 1

Estimated Unconditional Survival Probabilities

Comparison of Recent Studies Using Monthly Data

\begin{tabular}{|c|c|c|c|c|}
\hline & \multirow[b]{2}{*}{ Data Set } & \multicolumn{3}{|c|}{$\begin{array}{l}\text { Probability that AFDC Spell Lasts at } \\
\text { Least: }^{\text {L }}\end{array}$} \\
\hline & & 6 months & 12 months & 24 months \\
\hline This Study & California LDB 1987-1992 & 0.72 & 0.56 & 0.36 \\
\hline Blank and Ruggles (1996) & SIPP 1986, 1987 & $\mathbf{n} / \mathbf{a}$ & 0.45 & 0.25 \\
\hline Fitzgerald (1995) & SLPP 1984, 1985 & 0.65 & 0.48 & $\mathbf{n} / \mathbf{a}$ \\
\hline Gritz and MaCurdy (1992) & NLSY 1979-1989 & $\mathrm{n} / \mathrm{a}$ & 0.67 & $\mathbf{n} / \mathbf{a}$ \\
\hline Harris (1993) ${ }^{2}$ & PSID 1984-1989 (monthly) & 0.76 & 0.56 & 0.36 \\
\hline
\end{tabular}

'Since 1984, the PSID has collected monthly AFDC participation information. This is retrospective data and is collected at annual interviews.

${ }^{2}$ The calculations from Harris (1993) measure the probability that the spell lasts greater than each of the months shown in the table. All of the others measure the probability that the spell lasts greater than or equal to each of the months shown. 
Table 2

Distribution of Length of AFDC Receipt by Demographic Group Unconditional Estimates

\begin{tabular}{|c|c|c|c|c|c|}
\hline & \multirow{2}{*}{$\begin{array}{c}\text { Number of } \\
\text { Spells }\end{array}$} & \multicolumn{4}{|c|}{ Probability that a completed spell lasts: } \\
\hline & & $\begin{array}{c}<=6 \\
\text { months }\end{array}$ & $<=1$ year & $<=2$ years & $<=4$ years \\
\hline All & 12221 & 0.28 & 0.46 & 0.62 & 0.75 \\
\hline Single Parent (AFDC-FG) & 10348 & 0.27 & 0.45 & 0.62 & 0.75 \\
\hline Two Parent (AFDC-UP) & 1873 & 0.31 & 0.49 & 0.63 & 0.72 \\
\hline White & 5835 & 0.31 & 0.51 & 0.67 & 0.79 \\
\hline Hispanic & 2855 & 0.28 & 0.45 & 0.61 & 0.74 \\
\hline Black & 2639 & 0.23 & 0.41 & 0.57 & 0.70 \\
\hline Asian Refugee Groups & 458 & 0.10 & 0.19 & 0.31 & 0.43 \\
\hline Other & 390 & 0.24 & 0.42 & 0.62 & 0.78 \\
\hline Non-teen Head & 11120 & 0.28 & 0.47 & 0.63 & 0.76 \\
\hline Teen Head & 1101 & 0.21 & 0.37 & 0.51 & 0.67 \\
\hline Urban & 10647 & 0.27 & 0.45 & 0.61 & 0.74 \\
\hline Non-Urban & 1574 & 0.33 & 0.54 & 0.71 & 0.82 \\
\hline
\end{tabular}

Source: Author's tabulation of LDB 1 percent case file. 
Table 3

Descriptive Statistics for AFDC Spells

\begin{tabular}{|c|c|c|c|c|c|}
\hline & Mean & $\begin{array}{l}\text { Standard } \\
\text { Deviation }\end{array}$ & Minimum & Maximum & $\begin{array}{c}\text { \# Non-Missing } \\
\text { Observations }\end{array}$ \\
\hline Teen Head & 0.09 & & 0 & 1 & 12221 \\
\hline Head 20-24 & 0.23 & & 0 & 1 & 12221 \\
\hline Head 25-34 & 0.44 & & 0 & 1 & 12221 \\
\hline Head 35-44 & 0.20 & & 0 & 1 & 12221 \\
\hline Head 45-54 & 0.05 & & 0 & 1 & 12221 \\
\hline White & 0.48 & & 0 & 1 & 12221 \\
\hline Hispanic & 0.23 & & 0 & 1 & 12221 \\
\hline Black & 0.22 & & 0 & 1 & 12221 \\
\hline Filipino & 0.01 & & 0 & 1 & 12221 \\
\hline Cambodian & 0.01 & & 0 & 1 & 12221 \\
\hline Laotian & 0.01 & & 0 & 1 & 12221 \\
\hline Vietnamese & 0.02 & & 0 & 1 & 12221 \\
\hline Other Race & 0.03 & & 0 & 1 & 12221 \\
\hline Number of Kids & 1.65 & 1.11 & 0 & 12 & 12221 \\
\hline Pregnant 1/ & 0.09 & & 0 & 1 & 12221 \\
\hline Youngest Child $<=2$ & 0.38 & & 0 & 1 & 12221 \\
\hline Youngest Child 3-5 & 0.21 & & 0 & 1 & 12221 \\
\hline Youngest Child 6+ & 0.31 & & 0 & 1 & 12221 \\
\hline Male Head 2/ & 0.03 & & 0 & 1 & 12221 \\
\hline AFDC-UP & 0.15 & & 0 & 1 & 12221 \\
\hline \% Right Censored (RC) & 0.35 & & 0 & 1 & 12221 \\
\hline Length of Spell, if $\mathrm{RC}=0$ & 11.92 & 11.19 & 1 & 68 & 7960 \\
\hline Length of Spell, if $\mathrm{RC}=1$ & 23.71 & 17.97 & 1 & 71 & 4261 \\
\hline
\end{tabular}

Source: Author's tabulations of LDB 1 percent case file. The sample contains one observation per spell. Notes:

1/ Pregnant is equal to one if the woman is pregnant at the beginning of the spell and has no other children in the case.

2/ Male head is always equal to zero when AFDC-UP is equal to one. 
Table 4

Descriptive Statistics for AFDC Monthly Transitions Data

\begin{tabular}{|c|c|c|c|c|c|}
\hline & Mean & $\begin{array}{l}\text { Standard } \\
\text { Deviation }\end{array}$ & Minimum & Maximum & $\begin{array}{c}\text { \# Non- } \\
\text { Missing } \\
\text { Observations }\end{array}$ \\
\hline \multicolumn{6}{|l|}{ County Labor Market Variables } \\
\hline Unemployment Rate & 7.46 & 3.33 & 1.9 & 36.1 & 191294 \\
\hline Average Qtrly Earnings (1000s) & 6.699 & 1.085 & 4.108 & 10.160 & 191294 \\
\hline Ave. Qtrly Earnings, Services (1000s) & 6.585 & 1.046 & 2.842 & 9.642 & 191294 \\
\hline Ave. Qtrly Earnings, Retail (1000s) & 3.920 & 0.408 & 2.084 & 5.201 & 191294 \\
\hline $\ln$ (Employment) & 13.23 & 1.59 & 6.70 & 15.28 & 191294 \\
\hline $\ln$ (Service Employment) & 12.19 & 1.61 & 5.61 & 14.26 & 191294 \\
\hline $\ln$ (Retail Employment) & 11.55 & 1.48 & 4.09 & 13.42 & 191294 \\
\hline Employment/Population & 0.40 & 0.09 & 0.18 & 0.82 & 191294 \\
\hline \multicolumn{6}{|l|}{ Other County Variables } \\
\hline GAIN Part. Rate & 0.14 & 0.10 & 0 & 0.93 & 191294 \\
\hline GAIN \$/Partic. (1000s) & 2.16 & 1.45 & 0 & 8.01 & 191294 \\
\hline \multicolumn{6}{|l|}{ Neighborhood Variables } \\
\hline Urban-Inside & 0.86 & & 0 & 1 & 181728 \\
\hline Urban-Outside & 0.10 & & 0 & 1 & 181728 \\
\hline Rural & 0.04 & & 0 & 1 & 181728 \\
\hline MEDHINC (1000s) & 30.743 & 9.418 & 4.999 & 88.539 & 181728 \\
\hline \%FEMNVMAR & 0.25 & 0.07 & 0 & 0.77 & 181728 \\
\hline
\end{tabular}

Source: Author's tabulations of LDB 1 percent case file. There is one observation per monthly transition in the welfare spells data. 
Table 5

Estimates from Discrete Duration Model, $A$ ll Spells

(1)

Estimate
(2)

Estimate

$0.174 * * *$

(0.050)

Head 20-24

$0.163 * * * \quad(0.048)$

$0.149 * * *$

(0.050)

Head 25-34

$0.150 * * *$

$(0.049)$

0.200 ***

(0.056)

0.070

(0.076)

Head 45-54

$-0.119$

(0.029)

$-0.273 * * *$

$(0.030)$

Black

Filipino

Cambodian

$-0.158$

(0.067)

$-1.250 * * *$

(0.221)

Laotian

$-1.190 * * *$

(0.203)

$-1.430 * * *$

(0.134)

$-0.165$

(0.142)

$-0.053 * * * \quad(0.013)$

Number of Kids

Pregnant

Youngest Child 3-5

$-0.334 * * * \quad(0.049)$

$0.042 \quad(0.032)$

$0.141^{* * *} \quad(0.033)$

$0.367^{* * *} \quad(0.064)$

Male Head

AFDC-UP

$0.105^{* * *}$

$(0.035)$

$0.205 * * *$

(0.058)

0.087

(0.079)

0.042

(0.031)

$-0.148 * * *$

(0.035)

$-0.107$

(0.070)

$-1.188 * * *$

(0.232)

$-1.086 * * *$

(0.204)

$-1.369 * * *$

(0.137)

$-0.126$

(0.146)

$-0.056 * * *$

(0.014)

$-0.345 * * *$

(0.051)

0.032

(0.033)

$0.148 * * *$

(0.035)

$0.343 * * *$

$(0.066)$

$0.110 * * *$

$(0.036)$

$-0.176 * * *$

(0.058)

$-0.090$

$(0.062)$

Urban-Outside

MEDHINC

\%FEMNVMAR

GAIN \$ per participant

GAIN Participation rate AFDC\&FO Guarantee

Constant

Duration Dummies

Number of Observations

Log Likelihood

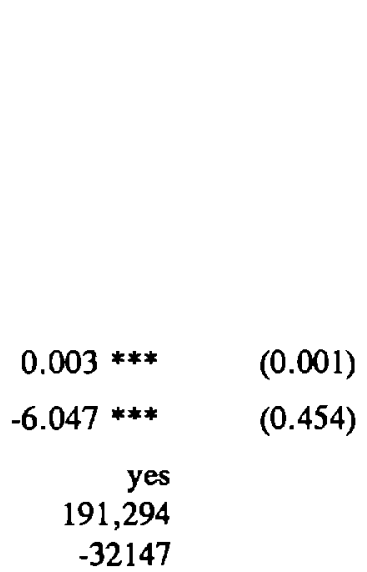

$0.006 * * *$

$-0.686 * * *$

$-0.022 * *$

$0.208 *$

$0.003 * * *$

$-5.941$

yes
181,728

$-30176$

$$
(0.001)
$$

Notes: Author's tabulations of LDB $1 \%$ file. Standard errors in parentheses. Asterisks indicate that the coefficient is significantly different from zero at the 10 percent $(*), 5$ percent $(* *)$, and 1 percent $(* * *)$ level. 
Table 6

Effects of Changes of Demographic Variables on the Distribution of Spell Length ${ }^{1}$

Probability that a completed spell lasts:

\begin{tabular}{|c|c|c|c|c|c|}
\hline & $\begin{array}{c}<=6 \\
\text { months }\end{array}$ & $<=1$ year & $<=2$ years & $\begin{array}{l}<=4 \\
\text { years }\end{array}$ & $\begin{array}{c}\text { Median } \\
\text { Length of } \\
\text { Spell } \\
\end{array}$ \\
\hline Baseline & 0.299 & 0.502 & 0.701 & 0.769 & 12 \\
\hline Male Head & 0.390 & 0.621 & 0.814 & 0.853 & 9 \\
\hline$\not$ Kids $=2$ & 0.286 & 0.483 & 0.681 & 0.754 & 13 \\
\hline$\not$ Kids $=4$ & 0.261 & 0.446 & 0.640 & 0.723 & 14 \\
\hline Pregnant & 0.225 & 0.392 & 0.577 & 0.671 & 18 \\
\hline Youngest child 3-5 & 0.307 & 0.513 & 0.712 & 0.778 & 12 \\
\hline Youngest child $6+$ & 0.337 & 0.553 & 0.752 & 0.808 & 11 \\
\hline AFDC-UP & 0.327 & 0.540 & 0.739 & 0.798 & 11 \\
\hline Hispanic & 0.289 & 0.488 & 0.686 & 0.758 & 13 \\
\hline Black & 0.265 & 0.453 & 0.648 & 0.729 & 14 \\
\hline Cambodian & 0.105 & 0.195 & 0.312 & 0.414 & 59 \\
\hline Laotian & 0.115 & 0.213 & 0.339 & 0.443 & 51 \\
\hline Vietnamese & 0.089 & 0.166 & 0.269 & 0.364 & $\underline{21}$ \\
\hline Teen parent & 0.265 & 0.453 & 0.648 & 0.728 & 14 \\
\hline Parent 20-24 & 0.305 & 0.510 & 0.709 & 0.776 & 12 \\
\hline Parent 35-44 & 0.313 & 0.521 & 0.720 & 0.784 & 12 \\
\hline Parent 45-54 & 0.285 & 0.481 & 0.679 & 0.753 & 13 \\
\hline Urban-Inside & 0.299 & 0.502 & 0.701 & 0.769 & 12 \\
\hline Urban-Outside & 0.321 & 0.531 & 0.731 & 0.792 & 12 \\
\hline Rural & 0.344 & 0.562 & 0.761 & 0.815 & 11 \\
\hline MEDHINC $+20 \%$ & 0.309 & 0.515 & 0.714 & 0.780 & 12 \\
\hline$\%$ FEMNVMAR + 0.07 & 0.288 & 0.486 & 0.684 & 0.756 & 13 \\
\hline GAINPT +0.10 & 0.299 & 0.501 & 0.700 & 0.769 & 12 \\
\hline GAIN \$/PT + 10\% & 0.378 & 0.606 & 0.801 & 0.844 & 9 \\
\hline AFDCFO $+10 \%$ & 0.359 & 0.582 & 0.780 & 0.828 & 10 \\
\hline
\end{tabular}

Notes:

1. Simulations based on estimates from model 2 in Table 5. Baseline case is a white, single mother aged 25-34 with 1 child $<3$, living inside the central city. All other variables are set to their mean values. The changes in the continuous variables are approximately equal to the variable's standard deviation.

2. The median for this group is longer than the sample period of 6 years. 
Table 7

Estimates from Discrete Duration Model

County Unemployment Rate

(1)

$\begin{array}{lll}-0.032 * * * & -0.039 * * * & -0.006 \\ (0.005) & (0.006) & (0.010) \\ & & \\ -0.027 & 0.269 * * * & 0.237 * * * \\ (0.017) & (0.045) & (0.047)\end{array}$

Qtrly Earnings, Services

(1000s)

Qtrly Earnings, Retail

(1000s)

Duration Dummies

County Fixed Effects

Time Effects

Number of Observations

Log Likelihood
(2)

(3)

(4)

(5)

$\begin{array}{ll}-0.003 & -0.002 \\ (0.010) & (0.010)\end{array}$

$0.151 * * *$

(0.028)

0.024

(0.130)

yes

yes

yes

yes

yes

yes

181,728

181,728

$-30056$ yes

yes

yes

181,728

$-30013$ yes

yes

yes

181,728

$-30024$

Notes: Author's tabulations of LDB 1\% file. Standard errors in parentheses. Asterisks indicate that the coefficient is significantly different from zero at the 10 percent $\left({ }^{*}\right), 5$ percent $\left({ }^{* *}\right)$, and 1 percent $\left({ }^{* * *}\right)$ level. Each specification also includes individual and family characteristics, GAIN variables, and neighborhood variables. See text for details. 
Table 8

Estimates from Discrete Duration Model

County Employment Growth

(1)

(2)

(3)

(4)

$\begin{array}{ccc}\ln (\text { Employment) } & 1.225 * * * & 1.079^{* * *} \\ & (0.298) & (0.319)\end{array}$

ln(Services Emp)

$0.851^{* * *}$

(0.239)

$\ln$ (Retail Trade Emp)

\begin{tabular}{ccc} 
& & $0.662 * *$ \\
& & $(0.268)$ \\
$0.234 * * *$ & $0.206 * * *$ & $0.231 * * *$ \\
$(0.047)$ & $(0.049)$ & $(0.048)$ \\
yes & yes & yes \\
yes & yes & yes \\
yes & yes & yes \\
& & \\
181,728 & 181,728 & 181,728 \\
-30009 & -30009 & -30013 \\
\hline
\end{tabular}

Quarterly Earnings

(1000s)

Duration Dummies

County Fixed Effects

Time Effects

$0.235 * * *$
$(0.044)$
yes
yes

181,728

$-30066$

$-30009$

$-30013$

Notes: Author's tabulations of LDB $1 \%$ file. Standard errors in parentheses. Asterisks indicate that the coefficient is significantly different from zero at the 10 percent $\left({ }^{*}\right), 5$ percent $\left({ }^{* *}\right)$, and 1 percent $\left(^{* * *}\right)$ level. Each specification also includes individual and family characteristics, GAIN variables, and neighborhood variables. See text for details. 
Table 9

Estimates from Discrete Duration Model

County Employment to Population Ratio

(1)

$5.115 * * *$

$(0.603)$

$0.294^{* * *}$

(0.045)

(1000s)

Qtrly Earnings, Services

(1000s)

Qtrly Earnings, Retail

(1000s)

Duration Dummies

County Fixed Effects

Time Effects

Number of Observations

Log Likelihood
(2)

$2.509 * * *$

(0.899)

$0.254^{* * *}$

$(0.047)$
(3)

(4)

$\begin{array}{ll}2.040^{* *} & 1.845^{* *} \\ (0.892) & (0.895)\end{array}$

(0.892)

$0.895)$
$0.154 * * *$

$(0.028)$

$-0.006$

$(0.130)$

yes

yes

yes

yes

yes

181,728

$-30038$
181,728

$-30011$
181,728

$-30010$
181,728

$-30025$

Notes: Author's tabulations of LDB $1 \%$ file. Standard errors in parentheses. Asterisks indicate that the coefficient is significantly different from zero at the 10 percent $\left(^{*}\right), 5$ percent $\left({ }^{* *}\right)$, and 1 percent $\left({ }^{* *}\right)$ level. Each specification also includes individual and family characteristics, GAIN variables, and neighborhood variables. See text for details. 
Table 10

Percent Change in Distribution of AFDC Spells under Alternative Labor Market Conditions ${ }^{1}$

\begin{tabular}{|c|c|c|c|c|c|}
\hline & \multicolumn{4}{|c|}{ Percent Change in Probability that a completed spell lasts: } & \multirow[b]{2}{*}{$\begin{array}{l}\text { Percent Change } \\
\text { in Caseload }\end{array}$} \\
\hline & $\begin{array}{c}<=6 \\
\text { months }\end{array}$ & $<=1$ year & $<=2$ years & $\begin{array}{l}<=4 \\
\text { years }\end{array}$ & \\
\hline \multicolumn{6}{|c|}{ (A) Unemployment Rate with County Fixed Effects- Table 7, Model (2) } \\
\hline Unemp. Rate -.03 & $10.2 \%$ & $8.6 \%$ & $6.5 \%$ & $4.5 \%$ & $-10.0 \%$ \\
\hline Earnings $+5 \%$ & $7.7 \%$ & $6.5 \%$ & $5.0 \%$ & $3.5 \%$ & $-8.0 \%$ \\
\hline \multicolumn{6}{|c|}{ (B) Employment Growth with County and Time Effects- Table 8, Model (2) } \\
\hline Employment $+10 \%$ & $9.0 \%$ & $7.3 \%$ & $5.3 \%$ & $3.6 \%$ & $-9.7 \%$ \\
\hline Earnings $+5 \%$ & $6.5 \%$ & $5.3 \%$ & $3.8 \%$ & $2.6 \%$ & $-7.1 \%$ \\
\hline \multicolumn{6}{|c|}{ (C) Employment Growth with County and Time Effects- Table 8, Model (3) } \\
\hline Services Employment $+10 \%$ & $7.0 \%$ & $5.7 \%$ & $4.1 \%$ & $2.8 \%$ & $-7.7 \%$ \\
\hline Earnings $+5 \%$ & $5.7 \%$ & $4.6 \%$ & $3.3 \%$ & $2.3 \%$ & $-6.3 \%$ \\
\hline \multicolumn{6}{|c|}{ (D) Employment Growth with County and Time Effects- Table 8, Model (4) } \\
\hline Retail Employment $+10 \%$ & $5.4 \%$ & $4.5 \%$ & $3.2 \%$ & $2.2 \%$ & $-6.0 \%$ \\
\hline Earnings $+5 \%$ & $6.4 \%$ & $5.2 \%$ & $3.8 \%$ & $2.6 \%$ & $-7.0 \%$ \\
\hline \multicolumn{6}{|c|}{ (E) Employment to Population Ratio with County and Time Effects- Table 9, Model (2) } \\
\hline $\mathrm{Emp} / \mathrm{Pop}+.035$ & $7.2 \%$ & $5.9 \%$ & $4.2 \%$ & $2.9 \%$ & $-8.0 \%$ \\
\hline Eamings $+5 \%$ & $7.0 \%$ & $5.7 \%$ & $4.1 \%$ & $2.8 \%$ & $-7.8 \%$ \\
\hline \multicolumn{6}{|c|}{ (F) Employment to Population Ratio with County and Time Effects- Table 9, Model (3) } \\
\hline $\mathrm{Emp} / \mathrm{Pop}+.035$ & $5.9 \%$ & $4.8 \%$ & $3.5 \%$ & $2.4 \%$ & $-6.5 \%$ \\
\hline Earnings, Services $+5 \%$ & $4.1 \%$ & $3.4 \%$ & $2.5 \%$ & $1.7 \%$ & $-4.6 \%$ \\
\hline \multicolumn{6}{|c|}{ (G) Employment to Population Ratio with County and Time Effects- Table 9, Model (4) } \\
\hline Emp/Pop +.035 & $5.3 \%$ & $4.4 \%$ & $3.2 \%$ & $2.2 \%$ & $-5.9 \%$ \\
\hline Earnings, Retail Trade $+5 \%$ & $-0.1 \%$ & $-0.1 \%$ & $-0.1 \%$ & $-0.0 \%$ & $0.1 \%$ \\
\hline
\end{tabular}

Notes:

1. Baseline case is a white, single mother aged 25-34 with 1 child less than 3. All other variables are set equal to their mean values. Changes in labor market variables represent median changes within counties over the sample period.

2. Changes in caseload calculated assuming the change is permanent and the entry rate is constant. 
Table 11

Estimated Labor Market Effects by Demographic Group

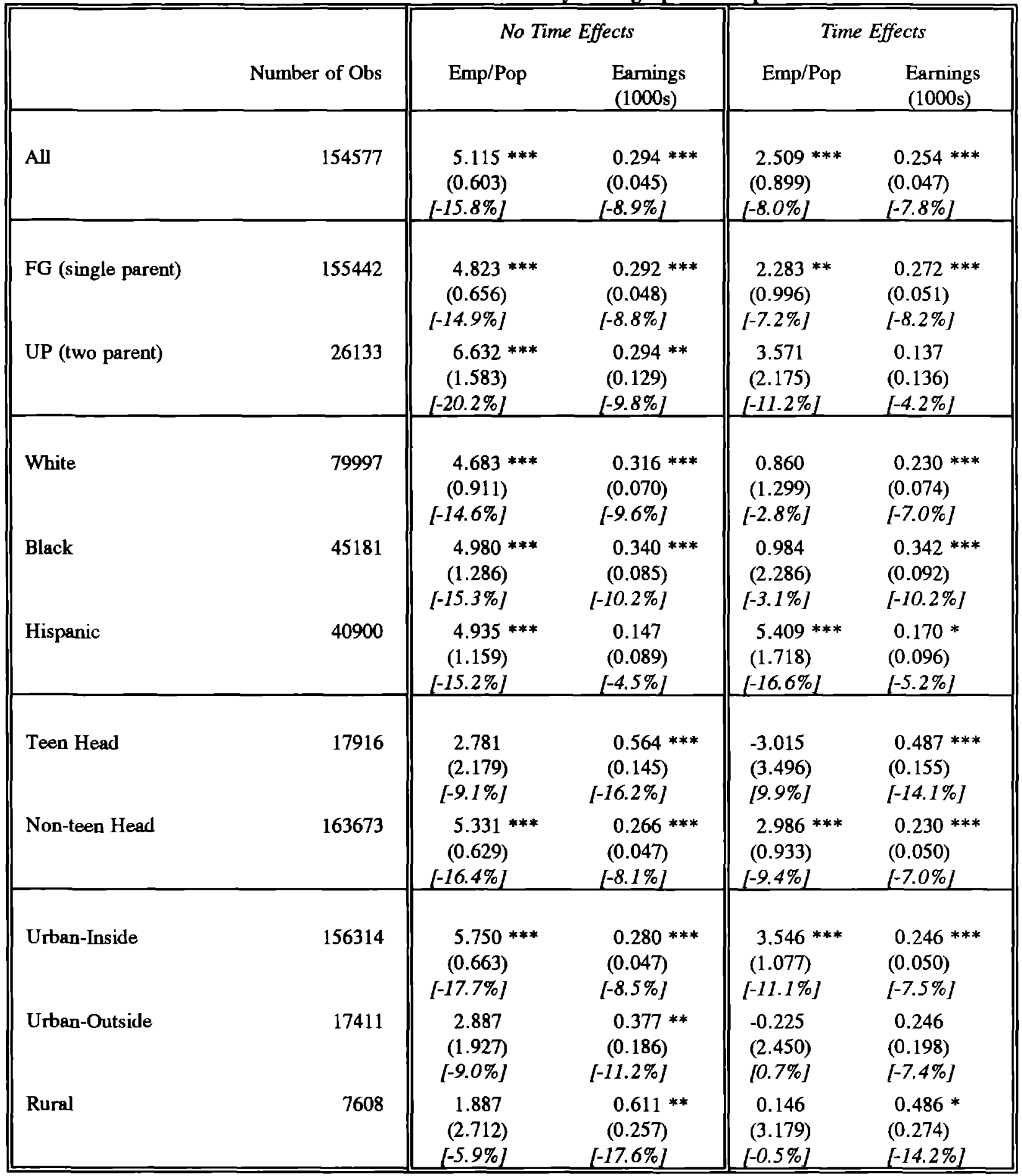

Notes: Two regressions are nun for each demographic group, one with time effects and one without. The regressions also control for family characteristics, neighborhood variables, duration dummies, and county fixed effects. The full set of estimates is available from the author. Standard errors in parentheses. Asterisks indicate that the coefficient is significantly different from zero at the 10 percent $(*), 5$ percent $\left(^{* *}\right)$, and 1 percent $\left({ }^{* * *}\right)$ level. The numbers in brackets [ are the percent change in the caseload, as calculated in the last column of Table 10. 
Table 12

Estimates of Duration Model Controlling for Endogeneity of Location

\begin{tabular}{|c|c|c|c|}
\hline & $\begin{array}{c}\text { Main Estimates } \\
\text { Table 9, Model (2) }\end{array}$ & Reduced Form & Instrumental Variables \\
\hline Employment / Population & $\begin{array}{l}2.509 * * * \\
(0.809)\end{array}$ & $\begin{array}{l}1.458 * * \\
(0.765)\end{array}$ & $\begin{array}{l}1.578 * * \\
(0.823)\end{array}$ \\
\hline $\begin{array}{l}\text { Quarterly Eamings, All } \\
\text { Industries (1000s) }\end{array}$ & $\begin{array}{l}0.254 * * * \\
(0.047)\end{array}$ & $\begin{array}{l}0.216 * * * \\
(0.043)\end{array}$ & $\begin{array}{l}0.230 * * * \\
(0.046)\end{array}$ \\
\hline $\begin{array}{l}\text { Duration Dummies } \\
\text { County Fixed Effects } \\
\text { Time Effects }\end{array}$ & $\begin{array}{l}\text { yes } \\
\text { yes } \\
\text { yes }\end{array}$ & $\begin{array}{l}\text { yes } \\
\text { yes } \\
\text { yes }\end{array}$ & $\begin{array}{l}\text { yes } \\
\text { yes } \\
\text { yes }\end{array}$ \\
\hline Number of Observations & 181,728 & 181,728 & 181,728 \\
\hline
\end{tabular}

